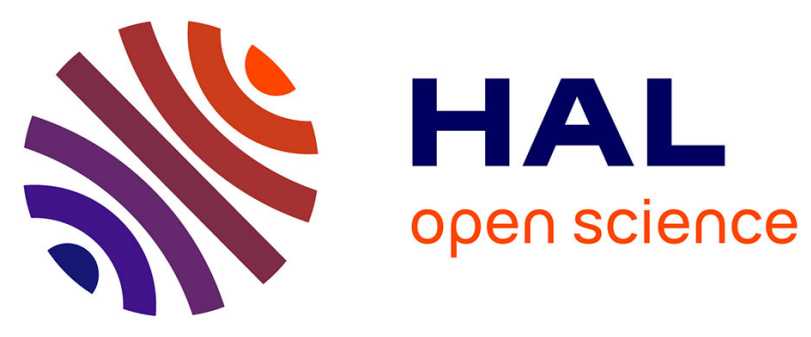

\title{
Modelling dendro-anthracological parameters with dendrochronological reference datasets: interrogating the applicability of anthraco-typology to assess Aleppo pine (Pinus halepensis Miller) wood management from archaeological charcoal fragments
}

Picornell-Gelabert Llorenç, Alexa Dufraisse, de Luís Martín, Mus Amézquita Maurici, Carrión Marco Yolanda

\section{- To cite this version:}

Picornell-Gelabert Llorenç, Alexa Dufraisse, de Luís Martín, Mus Amézquita Maurici, Carrión Marco Yolanda. Modelling dendro-anthracological parameters with dendrochronological reference datasets: interrogating the applicability of anthraco-typology to assess Aleppo pine (Pinus halepensis Miller) wood management from archaeological charcoal fragments. Journal of Archaeological Science, 2020, 124, pp.105265. 10.1016/j.jas.2020.105265 . mnhn-03011926

\section{HAL Id: mnhn-03011926}

\section{https://hal-mnhn.archives-ouvertes.fr/mnhn-03011926}

Submitted on 18 Nov 2020

HAL is a multi-disciplinary open access archive for the deposit and dissemination of scientific research documents, whether they are published or not. The documents may come from teaching and research institutions in France or abroad, or from public or private research centers.
L'archive ouverte pluridisciplinaire HAL, est destinée au dépôt et à la diffusion de documents scientifiques de niveau recherche, publiés ou non, émanant des établissements d'enseignement et de recherche français ou étrangers, des laboratoires publics ou privés. 


\section{Journal of Archaeological Science}

\section{Modelling dendro-anthracological parameters with dendrochronological reference datasets: interrogating the applicability of anthraco-typology to assess Aleppo pine (Pinus halepensis Miller) wood management from archaeological charcoal fragments --Manuscript Draft--}

\begin{tabular}{|c|c|}
\hline Manuscript Number: & JASC20-321R1 \\
\hline Article Type: & Research Paper \\
\hline Keywords: & $\begin{array}{l}\text { dendro-anthracology, anthraco-typology, charcoal-pith distance, diameter estimation, } \\
\text { radial growth, Pinus halepensis Miller, firewood/timber exploitation }\end{array}$ \\
\hline Corresponding Author: & $\begin{array}{l}\text { Llorenç Picornell Gelabert, Ph.D } \\
\text { University of the Balaeric Islands } \\
\text { Palma, Illes Balears SPAIN }\end{array}$ \\
\hline First Author: & Llorenç Picornell Gelabert, Ph.D \\
\hline \multirow[t]{5}{*}{ Order of Authors: } & Llorenç Picornell Gelabert, Ph.D \\
\hline & Alexa Dufraisse, $\mathrm{PhD}$ \\
\hline & Martín de Luís, PhD \\
\hline & Maurici Mus Amézquita, PhD \\
\hline & Yolanda Carrión Marco, PhD \\
\hline Abstract: & 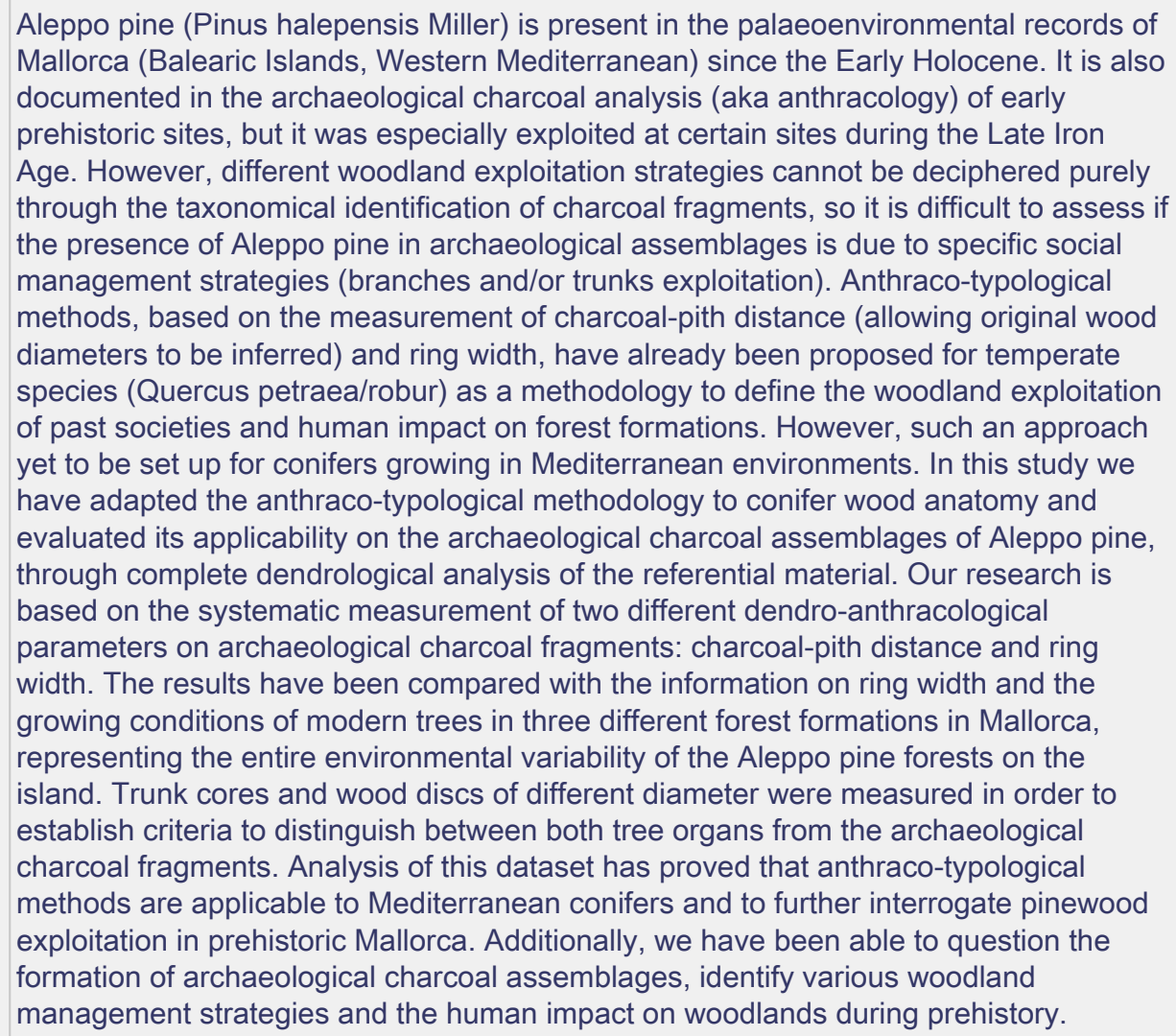 \\
\hline
\end{tabular}




\section{Highlights}

Dendro-anthracological and anthraco-typological methods are tested for Pinus halepensis.

A dendrochronological reference dataset has been created and analysed.

Anthraco-typological methods are proved to be applicable to Mediterranean conifers.

Archaeological charcoal fragments of Pinus halepensis has been studied.

Anthraco-typology allowed for the interrogation of pinewood exploitation practices. 
2 Modelling dendro-anthracological parameters with dendrochronological reference datasets: 3 interrogating the applicability of anthraco-typology to assess Aleppo pine (Pinus halepensis

4 Miller) wood management from archaeological charcoal fragments.

6 Picornell-Gelabert, Llorenç ${ }^{1 *}$; Dufraisse, Alexa ${ }^{2}$; de Luís, Martín ${ }^{3}$; Mus Amézquita, Maurici ${ }^{4}$;

7 Carrión Marco, Yolanda 5 .

9 *Corresponding author: LPG tokelau24@gmail.com

101 ArqueoUIB Research Team, Department of Historical Sciences and Theory of Arts. University of 11 the Balearic Islands, Carretera de Valldemossa Km 7,5, 07122, Palma, Mallorca, Spain. ORCID: 12 https://orcid.org/0000-0003-0662-110X.

132 CNRS/MNHN, UMR 7209 Archéozoologie, Archéobotanique: Sociétés, Pratiques et 14 Environnements, Sorbonne Université, CP56, 55 rue Buffon, 75005 Paris, France

153 Departamento de Geografía y Ordenación del Territorio - IUCA, Universidad de Zaragoza. C/ 16 Pedro Cerbuna, 12, 50009 Zaragoza, Spain.

174 Department of Biology. University of the Balearic Islands, Carretera de Valldemossa Km 7,5, 18 07122, Palma, Mallorca, Spain

195 PREMEDOC- GIUV2015-213. Universitat de València, Departament de Prehistòria, Arqueologia 20 i Història Antiga, Av. Blasco Ibañez 28, 46010 València, Spain. Yolanda.carrion@uv.es, ORCID: 21 https://orcid.org/0000-0003-4064-249X.

Abstract: Aleppo pine (Pinus halepensis Miller) is present in the palaeoenvironmental records of Mallorca (Balearic Islands, Western Mediterranean) since the Early Holocene. It is also documented in the archaeological charcoal analysis (aka anthracology) of early prehistoric sites, but it was especially exploited at certain sites during the Late Iron Age. However, different woodland exploitation strategies cannot be deciphered purely through the taxonomical identification of charcoal fragments, so it is difficult to assess if the presence of Aleppo pine in archaeological assemblages is due to specific social management strategies (branches and/or trunks exploitation). Anthraco-typological methods, based on the measurement of charcoal-pith distance (allowing original wood diameters to be inferred) and ring width, have already been proposed for temperate species (Quercus petraea/robur) as a methodology to define the woodland exploitation of past societies and human impact on forest formations. However, such an approach yet to be set up for conifers growing in Mediterranean environments. In this study we have adapted the anthracotypological methodology to conifer wood anatomy and evaluated its applicability on the 
1 archaeological charcoal assemblages of Aleppo pine, through complete dendrological analysis of

2 the referential material. Our research is based on the systematic measurement of two different 3 dendro-anthracological parameters on archaeological charcoal fragments: charcoal-pith distance and

4 ring width. The results have been compared with the information on ring width and the growing 5 conditions of modern trees in three different forest formations in Mallorca, representing the entire environmental variability of the Aleppo pine forests on the island. Trunk cores and wood discs of different diameter were measured in order to establish criteria to distinguish between both tree organs from the archaeological charcoal fragments. Analysis of this dataset has proved that anthraco-typological methods are applicable to Mediterranean conifers and to further interrogate pinewood exploitation in prehistoric Mallorca. Additionally, we have been able to question the formation of archaeological charcoal assemblages, identify various woodland management strategies and the human impact on woodlands during prehistory.

Keywords: dendro-anthracology, anthraco-typology, charcoal-pith distance, diameter estimation, radial growth, Pinus halepensis Miller, firewood/timber exploitation.

\section{Introduction}

19 The study of archaeological charcoal assemblages (anthracology) has been developed, to a relevant extent, on the prehistoric sites of the Balearic Islands (Western Mediterranean). This research has allowed the advancement of palaeoenvironmental approaches to past vegetation dynamics and enabled the analyses of the role of wood and firewood in past socio-environmental relations (i.e. Picornell-Gelabert 2012; Picornell-Gelabert and Servera-Vives 2017; Picornell-Gelabert and Carrión 2017; Picornell-Gelabert and Dufraisse 2018; Piqué and Noguera 2002). In this context, Aleppo pine appears to be an important tree in Balearic Holocene vegetation (Burjachs et al. 2017; Servera-Vives et al. 2018) as its presence in the anthracological record of Mallorca is well attested. However, percentages of pine in anthracological assemblages appear to fluctuate between different sites and chronologies. Aleppo pine is a lowland Mediterranean species with a high ecological plasticity and regeneration rate - especially after heavy or episodic fires, which are common in its natural habitat (Goubitz et al. 2003, Ne'eman et al. 2004) - and is a dominant tree species within the current forest cover of the Balearic archipelago (Gil et al. 2003). The development of extensive masses of secondary pine forests in Mallorca is seen, at least in part, as a consequence of anthropic

33 disturbance (Llorens et al. 2007) and centuries of human landscape management (Gil et al. 2003).

34 Evaluating the role of human landscape management in the development of Aleppo pine forests in the past and interpreting the variability of its representation in the anthracological record is difficult 
1 to assess using only taxonomical identification. This study, therefore, offers relevant information

2 beyond taxonomical identification, in order to better interrogate diverse pinewood management 3 practices and, subsequently, the impact of human exploitation of this tree species during prehistory.

4 Taxonomic identification is the basic information provided by all bioarchaeological disciplines. In 5 anthracology, taxonomic identification has been the cornerstone for palaeoecological and landscape 6 dynamic reconstructions and for the interrogation of past woodland management practices (e.g. 7 Asouti and Austin 2005; Chabal et al. 1999; Théry-Parisot et al. 2010). However, both ethnographic 8 (Picornell-Gelabert 2009; 2017; Picornell-Gelabert et al. 2011, Dufraisse et al. 2007) and 9 archaeological works (Dufraisse 2008) dealing with trees and forest resource management have 10 stated that there are other important variables beyond taxa which need to be taken into account if 11 the social management of woodlands is to be fully explained. Among these factors, the diameter of 12 exploited wood constitutes one of the key elements to understand wood exploitation practices 13 (Dufraisse 2012).

14 Determining the diameter of the wood exploited in the past remains a difficult task. Charcoal 15 fragments preserve the original wood anatomy, allowing their taxonomical identification, but when 16 the wood is burnt mass loss and fragmentation occurs. As a result, a direct estimation of the original 17 wood diameter is not possible after observing the wood anatomy of a single charcoal fragment. 18 Equally, diameter does not allow us to determinate the tree organ (trunk or branch) from which the 19 charcoal fragments originate.

20 In order to evaluate the exploited wood diameters of a taxon present in an archaeological charcoal assemblage, two steps are necessary: the first consists of evaluating the charcoal-pith distance in each charcoal fragment; the second is to recompose the exploited wood diameters from the measured charcoal-pith distances (Dufraisse and Garcia 2011).

24 However, fragments of small diameter can correspond to both the branches and/or the inner parts of bigger trunks. In order to distinguish between small fragments deriving from branches and trunks, radial growth (ring width) is also measured. This combination of dendro-anthracological parameters was initially tested on ring-porous angiosperm species growing in temperate forests in Western Europe (Quercus petraea/robur) (Dufraisse et al. 2018a). In this case, the distinction between heartwood and sapwood was added to tree-ring width and charcoal-pith distance, by means of the tylosis count in earlywood vessels (Dufraisse et al. 2018b). The combination of these three parameters led to an anthraco-typological approach, whose interpretations are based on the establishment of a modern dendrochronological reference dataset. Anthraco-typology for Quercus

33 f.c. is based on eight different anthraco-groups that, when applied to archaeological charcoal, allows

34 the exploitation of trunk, branches and/or entire trees in a given assemblage to be discriminated 35 (Dufraisse and Coubray 2018, Coubray and Dufraisse, 2019). We suggest that it also allows the 
1 appropriate charcoal fragments (i.e. eliminating branches) to be selected, enabling further specific

2 questions on the evolution of tree-ring widths through time and the impact of human exploitation 3 and climate on forests to be evaluated (Marguerie and Hunot 2007).

4 The anthraco-typological approach defined for Quercus f.c. is not directly applicable to 5 gymnosperms when considering their wood anatomy, as the heartwood-sapwood discrimination 6 tool is not suitable because of the absence of vessels and, subsequently, of tylosis. In order to 7 discriminate trunks from branches in gymnosperms, the combination of ring widths and charcoal8 pith distance is considered as a potentially discriminant factor, as has been shown for Quercus f.c 9 (Dufraisse et al. 2018a).

10 In this sense, the objectives of this study are:

i) To test and validate the applicability of an anthraco-tyopological approach based on the combination of charcoal-pith distance and tree-ring widths according to gymnosperms wood anatomy growing in Mediterranean environments (Aleppo pine, Pinus halepensis Miller);

ii) To build up a referential model of the radial growth (tree-ring width) depending on diameters and tree organs of Aleppo pine in Mallorca, according to different ecological conditions, in order to allow specific interpretation of the anthraco-typological approach;

iii) To test the application of the anthraco-typology approach on Aleppo pine charcoal fragments in order to further interrogate pinewood uses and exploitation stategies on archaeological sites from Mediterranean environments. In this sense, the referential dendrochronological dataset turned out to be imperative, as the radial growth on trunks and branches from the same individuals had not been approached before.

22 This research was conducted on the island of Mallorca (Figure 1). Different pine populations from diverse biogeographic zones were studied in order to characterise the radial growth of both tree organs: trunk and branches. The results were then analysed in order to validate the applicability of anthraco-typology principles. Finally, the model established after the referential study was applied to different archaeological charcoal assemblages from prehistoric and protohistoric sites on the

27 island.

Figure 1: Map of the island of Mallorca showing the location of the forest stations sampled for the reference dendrochronological dataset and the archaeological sites studied

\section{2. Materials and methods}

33 The methodology used consists of the measurement of two dendro-anthracological parameters

34 (diameter and ring width) from both archaeological wood charcoal fragments and modern Aleppo 35 pine samples, and in the interrogation of the results using anthraco-typological principles (Figure 2). 
1 Accordingly, two different kinds of dataset were produced: i) a dendrochronological study of

2 current Aleppo pine populations in Mallorca, measuring tree-ring width in trunks and branches

3 according to diameter; and ii) the application of different dendro-anthracological parameters to

4 Aleppo pine archaeological charcoal fragments, comprising measurements of the missing radius

5 (charcoal-pith distance), modelling diameter (ADmodel) and tree-ring width. This allowed for the application of the anthraco-typological principles to the obtained dendro-anthracological datasets according to the results of the dendrochronological referential.

9 Figure 2: Synthesis of the developed methodological approach, combining the study of modern 10 dendrochronological reference datasets and dendro-anthracological analysis of Aleppo pine 11 archaeological charcoal fragments.

\subsection{Referential study of the radial growth of Aleppo pine in Mallorca}

14 In order to obtain a dendrochronological referential dataset of Aleppo pine, 53 trees from 4 different 15 populations of this species were studied (Table 1). The sampling stations were distributed along the different biogeographic regions of the island representing diverse altitudes and annual precipitation rates (Table 1; Figure 1). At each site, dominant and codominant trees with no visible damage were selected and cored twice at breast height $(1.3 \mathrm{~m})$, perpendicular to the slope direction so as to avoid tension wood anomalies when using Pressler increment borers. In addition, two wood discs from branches were obtained from each tree using a hand saw. In the laboratory, the cores and wood discs were air-dried and sanded with progressively finer grades of sandpaper (80, 180, 300, 500 grit) until the tree-ring structure was clearly visible under the stereo microscope. Later, the cores were scanned and cross-dated using CooRecorder v8.0 (Larsson, 2013) and verified by COFECHA software (Holmes, 1994). Finally, the tree-ring width measurements were done to the nearest 0.01 mm using TSAP-Win ${ }^{\mathrm{TM}}$ and LINTAB ${ }^{\mathrm{TM}}$ (Rinntech, Heidelberg, Germany).

Table 1: Description of the forest stations sampled for the referential dendrochronological study

The main objectives of this referential study were: i) to characterise the growth trends of Aleppo pine in Mallorca, and ii) to characterise the growth rate in trunks and branches. Growth trends are characterised in dendroecology by combining ring width and cambial age. However, although cambial age is not measurable on archaeological charcoal fragments, the charcoal-pith distance can be calculated using a trigonometric tool, and the growth ring patterns in segments of cambial age are suitable to approach forest dynamics and development (Haneca et al. 2005). In this study, we considered the combination of ring width and diameter classes as a relevant proxy to characterise 
1 and interrogate the dendro-anthracological results. Accordingly, the average ring width of the

2 different trees sampled was calculated for each cambial age and also for each diameter class,

3 obtaining a dendrochronological referential comparable to the dendro-anthracological results.

4 To characterise the trunk growth trends of Aleppo pine, the average ring width was calculated for 5 both the cambial age and diameter classes on 38 trees from 3 different stations (Table 1). To 6 characterise the growth rate of trunk and branches, three stations and five trees from each one were 7 additionally sampled (Table 1). In this case, a trunk core and three to four wood slides from 8 branches of different diameters were sampled and measured. The average ring width of both organs

9 (trunk and branches) was calculated in relation to cambial age and diameter classes. The results 10 were compared to attempt to discriminate trunk and branches radial growth on archaeological 11 charcoal fragments when combined with charcoal-pith distance (see section 3.1).

\section{2.2. Archaeological charcoal assemblages analysed}

14 The anthraco-typological approach was applied to five different assemblages of dispersed charcoal 15 fragments from three sites in Mallorca, dating from the Late Bronze Age to the Late Iron Age/Early 16 Roman period (Figure 1). The main characteristics of the assemblages are summarised in Table 2.

Table 2: Description of the archaeological charcoal assemblages analysed

Three of the assemblages originate from a fire, in which it is assumed that the timber burnt down and fragmented. As a consequence, the pine fragments may potentially represent both firewood and/or timber remains and be subsequently overrepresented in the anthracological spectra. This is the case of the two assemblages from Building 51 in Ses Païsses - one corresponding to the habitat level and one to the roof collapse - and the assemblage of the Talaiot 3 in Son Fornés, a towershaped public monument inside the village.

The other two assemblages originate from archaeological deposits formed after a deliberate abandonment. The assemblage from the interior of Building 25 in Ses Païsses corresponds to dispersed charcoal fragments linked to metallurgical activity: firewood residues covering a relatively long time span.

30 Finally, the assemblage from the $\mathrm{Na}$ Galera site, located in a small islet near the Mallorca shore, is the result of residue deposits from a cistern reused as a dump. In this case, the assemblage showed an abundance of big charcoal fragments, most of which were pine. As the associated building presents several collapsed and rebuilding phases, the original excavators hypothesised that this charcoal assemblage represents timber remains. 


\section{$1 \quad 2.3$ Dendro-anthracological tools}

\section{2.3.1. Measurement of the charcoal-pith distance}

3 Different methodologies have been proposed to calculate the distance between the charcoal

4 fragment and the pith of the trunk/branch from where it originated (radius) and to infer a minimum

5 diameter for the original wood (radius x2) (see a detailed analysis in Dufraisse et al. 2019). Among

6 these, estimating the missing radius based on the trigonometric tool of a right-angled triangle

7 provided reliable measurements and estimations of the original diameters of charcoal fragments.

8 This technique and the correction factors were tested on seven taxa (including Pinus halepensis)

9 providing relevant results and systematising the use of the pith-location tool for wood diameter 10 estimation (Dufraisse et al. 2019).

11 The pith-location tool is based on the measurement of the angle and the distance between two 12 ligneous rays at its intersection with the ring boundary.

13 All measurements were taken using a Nikon AZ100 macroscope with magnifications from x 5 to $14 \mathrm{x} 400$, associated with a Nikon camera. The measurements of the distance and the angle between 15 two ligneous rays were obtained using a semi-automatic system based on four landmarks integrated 16 into the Nikon NIS Elements software. The calculation of the charcoal-pith distance, based on the 17 trigonometry of an isosceles triangle, was automatically done by the software (Figure 2).

18 The measurements were obtained on the last preserved tree ring of every fragment. For each fragment, five separate measurements using different rays crossing at the same ring boundary were obtained. The two extreme values obtained for the charcoal-pith distance (the largest and the shortest) were discarded and a mean value of the remaining three measurements was calculated. The projected diameter (charcoal-pith distance $\mathrm{x} 2$ ) was then established for every fragment. Diverse experimental studies on fresh and carbonised wood, especially on Pinus halepensis Miller (Dufraisse et al. 2020, García and Dufraisse 2011), allowed us to establish exclusive criteria to reduce the margins of error and improve the archaeological application of the pith-location tool, and to establish correction factors linked to the tool (i.e. under and overestimation) (Dufraisse and Garcia 2011; Garcia and Dufraisse 2011). Accordingly, the exclusive criteria used in this study were:

i) Measurements of distance between the two rays $<2 \mathrm{~mm}$ were excluded;

ii) Angle between the two rays $<2^{\circ}$ were excluded; and the correction factors applied were:

iii) A correction factor linked to the trigonometric tool was applied due to the underestimation by $20 \%$ of the missing radius on projected diameter classes between $5 \mathrm{~cm}$ and $10 \mathrm{~cm}$;

iv) No reliable measurements of charcoal-pith distance $>12.5 \mathrm{~cm}$ were considered;

v) A correction factor taking into account wood shrinkage during carbonisation (20\%) was 
applied to the measurement of the charcoal-pith distance.

2 The final value was classified according to different (projected) diameter classes established by the

3 standard dendrometrical plans used by foresters (Gaudin 1996; Deleuze et al. 2014). In such 4 models, conventional wood cuts are $4 \mathrm{~cm}, 7 \mathrm{~cm}, 20 \mathrm{~cm}$, etc. For gymnosperms, Deleuze et al. 5 (2014) propose to include additional cuts of $14 \mathrm{~cm}$. According to the experimental studies, 6 especially wood shrinkage (García and Dufraisse 2011) and the precision of the archaeological questions, we also added cuts of $2 \mathrm{~cm}$ and $10 \mathrm{~cm}$, resulting in the following projected diameter classes: [0-2] cm; [2-4] cm; [4-7] cm; [7-10] cm; [10-14] cm; [14-20] cm and [>20 cm.

\subsubsection{Diameter analysis tool (ADmodel)}

11 During carbonisation wood experiences both mass loss and fragmentation, so the measured charcoal-pith distance (and the projected diameter) on charcoal fragments does not represent the unburnt wood diameter. In order to correct this bias, the Analysis Diameter tool (ADmodel) was established, based on the fact that every trunk is biologically considered to be a stack of cones. This model assists in interpreting the distribution of the charcoal-pith distances from a charcoal assemblage of theoretical unburnt wood diameters (Dufraisse 2006). The ADmodel, developed by the DENDRAC project, is available (for both gymnosperms and angiosperms) as an open access Excel macro on the project's website (https://dendrac.mnhn.fr/spip.php?article237).

\subsubsection{Radial growth (tree-rings width and growth rate)}

Ring width was measured for the preserved tree rings visible in each charcoal fragment using the Nikon AZ100 macroscope, the Nikon camera and NIS Elements software. A correction factor (20\%) was applied to all the measures obtained due to wood shrinkage during carbonisation (Dufraisse et al. 2018a). An average ring-width value was calculated for each fragment and considered in relation to the projected diameter class calculated for the same fragment. An average value for the ring width of all the fragments for every projected diameter class in each assemblage was also calculated. This data was analysed according to the results of the referential study on the radial growth of Aleppo pine trees in Mallorca (see section 3.1).

\subsection{Anthraco-typology: theoretical principles and referential model}

In order to easily compare the dendro-anthracological data between the archaeological charcoal

32 fragments and the referential model, the principles of anthraco-typology (i.e. the combination of the 33 dendro-anthracological parameters) were applied (Dufraisse et al. 2018a; Dufraisse and Coubray 34 2018). Considering the wood anatomy of gymnosperms and the combination of two dendroanthracological parameters (charcoal-pith distance and growth rate), a total of four anthraco-groups 
1 were defined based on two different variables of the charcoal fragments: projected diameter classes

2 and average ring width (Figure 3).

3 According to the standard dendrometrical parameters used by foresters, a threshold between 4 trunk/branches was established at $7 \mathrm{~cm}$ of the diameter (Gaudin 1996; Deleuze et al. 2014).

5 Moreover, the dendrochronological referential of the Aleppo pine in Mallorca allows the 6 interrogation of different growth rates for both organs, trunks and branches, discriminating between

7 fast and slow growth (see section 3.1). Accordingly, by combining these two parameters, measured

8 both on the referential and on the archaeological materials, four anthraco-groups were considered as

9 discriminating between small and large diameters $(</>7 \mathrm{cmn})$ and fast and slow growth $(</>$ 10 threshold established after the dendrochronological referential) (Figure 3).

12 Figure 3: Synthesis of the anthraco-groups defined by the anthraco-typology principles adapted to 13 gymnosperms' wood anatomy.

\section{3. Results}

\section{3.1 Dendrochronological results of the referential study}

18 3.1.1 Growth trends of Aleppo pine populations in Mallorca

19 The trunk cores of the three stations presented similar growth trends, characterised by fast or very

20 fast growth in juvenile trees that is progressively reduced due to the age effect (Figure 4a). This 21 growth trend is coherent with other Aleppo pine populations studied along the Mediterranean Basin 22 (de Luís et al. 2013) and is maintained when ring width is plotted against diameter classes, as with 23 anthracology (Figure 4b).

24 These three Mallorcan pine populations showed similar responses to climate and a parallel evolution between the three different stations (Figure 4a). However, although the annual trend of the three stations described parallel curves, they presented different ring-width values. The stations presenting the highest ring widths (Binissalem and Caimari) recorded the highest average annual precipitation, and the station with the lowest ring widths (Ses Salines) documented the lowest average annual precipitation (see Figure 4a and Table 1). This suggests that one of the most relevant factors conditioning the growth of Aleppo pine in Mallorca is precipitation, a trend that is coherent with the available dendroecological studies for this species across its present distribution (de Luis et 32 al. 2013).

34 Figure 4: Results of the dendrochronological measurements of trunk cores from referential stations: 
$2 \quad 3.1 .2$ Growth rate of trunk and branches

3 Radial growth measurements were compared in trunk and branches with the same cambial age in 15

4 different trees from 3 stations (Table 1). Ring width is significantly different for the trunk and

5 branches of the same cambial age in all the stations, but is remarkably smaller for branches (Figure

6 5a). Again, this growth trend is maintained when replacing cambial age by diameter classes (Figure $75 b)$.

9 Figure 5: Results of the dendrochronological measurements of trunk cores and branches from 10 referential stations: a) ring width vs. cambial age; $b$ ) ring width vs. diameter classes.

12 Considering all the ring widths measured for trunks and branches from the 15 trees in the 3 different 13 stations, mean values between trunks and branches were different in every station according to 14 different climatic conditions (precipitation) (Figure 6a). Also, when considering each station 15 independently and then all the stations together, the average ring width was always $>1.5 \mathrm{~mm}$ for 16 trunks and $<1.5 \mathrm{~mm}$ for branches.

17 When the ring width of all the sampled trees was calculated for each diameter class (considering 18 both trunks and branches together), this $1.5 \mathrm{~mm}$ value divided the diameter classes above and under $197 \mathrm{~cm}$ (Figure 6b). Considering these results, ring width was also plotted on samples above and 20 under $7 \mathrm{~cm}$ of diameter for both trunks and branches (Figure 6c). In this case, it is clearly visible 21 that both groups are divided at $1.5 \mathrm{~mm}$ of ring width: $>1.5 \mathrm{~mm}$ in the trunk samples and $<1.5 \mathrm{~mm}$ 22 in the branch samples.

24 Figure 6: A boxplot and a mean and whisker plot of the ring width measurements for the trunk and branches from referential stations: a) ring width for trunks and branches by each station and altogether; b) ring width by diameter classes for trunks and branches from all the stations; $c$ ) ring width by $<$ and $>7 \mathrm{~cm}$ of diameter on trunk and branches from all the stations.

These results allowed us to establish two thresholds differentiating trunks and branches according to diameter and ring width, applicable to the archaeological charcoal fragments. Both values enable the application of the anthraco-typological principles as follow:

i) Diameters above and under $7 \mathrm{~cm}$ can be considered as the distinction between trunks (>

$337 \mathrm{~cm})$ and branches $(<7 \mathrm{~cm})$; this referential study confirms the standard ranking used by foresters 34 for Aleppo pine;

ii) There is a quantitative difference in the radial growth of trunks and branches for Aleppo 
1 pine that clearly defines differentiated growth rates for both organs of the tree: $<1.5 \mathrm{~mm}$ for

2 branches and $>1.5 \mathrm{~mm}$ for trunks.

4 3.2. Anthraco-typology: establishment of the anthraco-groups according to the 5 dendrochronological reference dataset.

6 According to the results obtained from the referential study, the established thresholds for diameter 7 and growth trends for trunks and branches can be used to discriminate between these two tree 8 organs, after the dendro-anthracological measurements of archaeological charcoal fragments 9 according to diameter classes $(<7 \mathrm{~m}$ vs. $>7 \mathrm{~cm})$ and ring width $(<1.5 \mathrm{~m}$ vs. $>1.5 \mathrm{~mm})$. Both 10 parameters were therefore used to organise the dendro-anthracological data, according to the 11 anthraco-typological principles adapted to gymnosperms wood anatomy (see section 2.3), and 12 characterise the four different anthraco-groups established (Figure 3):

i) Small diameter $(<7 \mathrm{~cm})$ and slow growth $(\mathrm{RW}<1.5 \mathrm{~mm})$ represents branches;

ii) Small diameter $(<7 \mathrm{~cm})$ and fast growth $(\mathrm{RW}>1.5 \mathrm{~mm})$ represents internal part of mature woods;

iii) Large diameter $(>7 \mathrm{~cm})$ and slow growth $(\mathrm{RW}<1.5 \mathrm{~mm})$ represents external parts of major trunks characterised by slow growth;

iv) Large diameter $(>7 \mathrm{~cm})$ and fast growth $(\mathrm{RW}>1.5 \mathrm{~mm})$ represents external parts of major trunks characterised by fast growth.

\subsection{Dendro-anthracological and anthraco-typological results on archaeological charcoal} assemblages

3.3.1. Minimum diameter estimation results (charcoal-pith distance and ADmodel)

24 The results obtained after measuring the charcoal-pith distances are shown in Table 3. The percentage of fragments corresponding to each diameter class are expressed both before and after the application of the ADmodel. It is significant to remark that the trends shown by both values did not present significant variances (Figure 7a). The only remarkable variation between both values is found in the case of the Talaiot 3 in Son Fornés.

Table 3: Results of the charcoal-pith distance measurements expressed by diameter classes and modelled according to the ADmodel.

33 Figure 7: Results of the dendro-anthracological measurements on archaeological charcoal 34 fragments of Aleppo pine: a) charcoal-pith distance and ADmodel; b) average ring width by 35 diameter classes. 
2 The two Late Bronze Age levels of Building 51 (Ses Païsses) show projected diameters generally 3 smaller than $7 \mathrm{~cm}$ (Figure 7a). The wood collection is oriented towards the same diameter classes in 4 both the fallen roof and the occupation level. We observed, however, a slight difference in the fallen 5 roof level in relation to the occurrence of bigger diameters, though its appearance is noticeably 6 reduced. The Iron Age assemblages of Building 25 (Ses Païsses) and Talaiot 3 (Son Fornés) also 7 show the exploitation of small woods, although the projected diameters are oriented towards larger 8 values, between 4 and $7 \mathrm{~cm}$. Moreover, the occurrence of bigger diameters, up to $20 \mathrm{~cm}$, is clearly 9 represented. Finally, the results of $\mathrm{Na}$ Galera show a clear predominance of small diameters, 10 specifically fragments under $4 \mathrm{~cm}$.

\section{3.3.2. Radial growth results (ring width and diameter classes)}

13 The results obtained by measuring the average ring width of the fragments of every diameter class 14 were variable for each assemblage (Figure 7b). In Building 51 (Ses Païsses) both assemblages 15 (occupation layer and faller roof) show remarkably narrow ring widths, mostly under $1 \mathrm{~mm}$ or less, 16 in all diameters classes. In the Iron Age assemblages from Building 25 (Ses Païsses) and Talaiot 3 17 (Son Fornés), ring width is remarkably higher (more than double) than in Building 51 and clearly above the established $1.5 \mathrm{~mm}$ threshold. Finally, the ring width measured at $\mathrm{Na}$ Galera is variable along the different diameter classes: it is low and predominantly under the $1.5 \mathrm{~mm}$ threshold for diameter classes smaller than $7 \mathrm{~cm}$; only a few fragments with diameters above a $7 \mathrm{~cm}$ ring width clearly exceed this value.

\subsubsection{Anthraco-typology}

24 The results of the charcoal-pith distance and the ring width measurements were sorted, according to the anthraco-typological principles and the definition of the anthraco-groups, and reviewed against the results obtained from the referential study (results expressed in Table 4 and Figure 8). The two levels of Building 51 (Ses Païsses) were characterised by a clear predominance of anthraco-group 1. However, both levels were differentiated by a higher presence of anthraco-group 2 in the roof collapse layer than in the habitat layer. In contrast, the Iron Age assemblages from Building 25 (Ses Païsses) and Talaiot 3 (Son Fornés) were characterised by a predominance of anthraco-groups 2 and 4. Finally, the results from $\mathrm{Na}$ Galera again showed a clear predominance of anthraco-group 1, followed by anthraco-group 2. 
typology principles.

3 Figure 8: Anthraco-typology diagrams for each archaeological assemblage (values expressed as \% 4 of fragments for each of the anthraco-groups).

\section{4. Discussion}

8 4.1. Dendrochronological reference dataset: modelling of the dendro-anthracological 9 parameters for Aleppo pine

10 Two different referential datasets were created from the pine populations in Mallorca - one 11 reflecting radial growth in pine trunks, the other comparing the radial growth of trunk and branches 12 in the same individuals. These enabled us to test the applicability of dendro-anthracological 13 parameters and tools, and the reliability of an anthraco-typological approach to Aleppo pine 14 charcoal fragments.

15 The radial growth of trunks is characterised by fast growth in juvenile trees and a subsequent 16 decrease of the growth rate due to the age effect (Figure 4a). This pattern also evidences the 17 replacing of cambial age by diameter classes (Figure $4 \mathrm{~b}$ ), an aspect that can be measured on archaeological charcoal fragments (charcoal-pith distance). The average ring width in trunks was variable from one station to another (Figure 4a). As the three different stations used cover a range of climatic variance, especially in relation to average annual precipitation (Table 1), it can be suggested that this growth variation is linked to climatic variables, coherent with other Aleppo pine populations studied (de Luís et al. 2013). Differences in radial growth for both the trunk and branches of the same individual trees are shown for both tree organs. Again, the growth rate of trunks was variable among the three stations (Figure 5a) according to the average annual precipitation (Table 1). In all cases, the radial growth of branches was significantly lower than that of trunks for the same cambial age, a pattern that is also clear when replacing the cambial age for the diameter classes (Figure 5b). Moreover, even if branches may be sensitive to climatic events (possible registration of extreme years in the dendrochronological curves of branches), no overlapping with the radial growth of trunks and branches with the same cambial age (Figure 5a) and/or diameter class (Figure 5b) was detected. Both curves presented distinctively different growth rates, significantly lower in branches, independently of the different climatic conditions recorded in

32 the three pine populations studied. The average measured ring width values for individual trees at 33 the three stations also show a clear differentiation between trunks and branches. The results, both in 34 every station and combined, highlight a distinction between the growth rate of both tree organs

35 (Figure 6a). If we consider the measured ring width from all the stations in relation to the diameter 
1 classes, the values obtained clearly indicate a parallel increase of diameter and ring width (Figure

$26 \mathrm{~b}$ ), confirming the $1.5 \mathrm{~mm}$ threshold discrimination between diameters $>$ and $<7 \mathrm{~cm}$ (Figure 6c).

3 The results obtained in this referential study also show that the accumulated branch radius did not 4 exceed $3.5 \mathrm{~cm}$, that is $7 \mathrm{~cm}$ of the diameter (Figure 5b), confirming the $7 \mathrm{~cm}$ threshold used by 5 foresters to distinguish between trunk and branches for Aleppo pine (Gaudin 1996; Deleuze et al.

6 2014). This, together with the clearly distinguished growth rate of both organs (< and $>1.5 \mathrm{~mm})$, attests that the different radial growth trends of Aleppo pine are linked to the different organs of the

8 tree (trunk and branches), regardless of the ecological growing conditions in Mallorca. The

9 combination of both parameters (ring width and diameter classes) allows for the discrimination

10 between trunks and branches after the dendro-anthracological analysis of archaeological charcoal 11 fragments.

\subsection{The reliability of the anthraco-typological approach to Aleppo pine archaeological} 14 charcoal fragments.

15 4.2.1. The applicability of anthraco-typology to Aleppo pine archaeological charcoal fragments

16 Considering the results of the referential dendrochronological model, we can see that the applicability of the dendro-anthracological parameters and tools and the anthraco-typology principles offer a relevant opportunity to better interrogate the Aleppo pine archaeological charcoal fragments to identify past uses of this tree.

The charcoal-pith distance measurements and results, expressed as the occurrence of different diameters classes, provides a general picture of wood diameters exploited in the past for a given charcoal assemblage. The occurrence of big diameter classes indicates the presence of medium/big wood logs, while the ADmodel helps identify the possible underrepresentation of small diameter classes (section 3.3, Figure 7a). In any case, as the original provenance of small diameter classes cannot be established solely using the charcoal-pith distance, as they can represent both branches and/or the internal part of bigger trunks, it needs to be considered alongside other proxies.

27 Radial growth, which can be modelled using modern dendrochronological datasets, has therefore been established as a parallel proxy to distinguish between trunk and branch exploitation. As previously mentioned (section 4.1), the growth trends of trunks and branches differs significantly, with a clear threshold emerging from the referential dataset, showing that branch growth is $<1.5$ $\mathrm{mm}$ and trunk growth is $>1.5 \mathrm{~mm}$ (Figure 6).

32 This differential radial growth in trunk and branches, together with the distinction between both tree 33 organs of $7 \mathrm{~cm}$ diameter (Figure $5 \mathrm{~b}$ ), allows the application of anthraco-typological principles to 34 Aleppo pine charcoal fragments. Combining both proxies and considering the referential model, the results of the dendro-anthracological measurements of charcoal fragments can be organised into 
1 four anthraco-groups for each assemblage (section 3.2, Figure 8). Accordingly, the measurement of

2 dendro-anthracological parameters (charcoal-pith distance and ring width) and their subsequent

3 organisation into anthraco-typological groups allows us to distinguish past pinewood exploitation 4 models.

6 4.2.2. Anthraco-typology applied to archaeological charcoal assemblages: characterisation of 7 pinewood exploitation in prehistoric and protohistoric sites in Mallorca

8 Dendro-anthracological parameters (charcoal-pith distance and ring width) were measured in 9 Aleppo pine charcoal fragments from five prehistoric and protohistoric sites in Mallorca (Table 2).

10 The results, according to the different anthraco-groups, allowed the management practices of 11 Aleppo pine to be proposed for specific archaeological contexts. In Building 51 (Ses Païsses), 12 anthraco-group 1 (corresponding to a small diameter $<7 \mathrm{~cm}$ and slow growth $<1.5 \mathrm{~mm}$, representing 13 branches) was predominant in both assemblages, corresponding to the habitat layer and the fallen 14 roof after the fire event (Figure 8). Accordingly, pine branches constitute a relevant part of the 15 charcoal assemblage in these contexts and would have been used as firewood to provide light and calorific energy to the activities carried out there. Anthraco-groups 3 (large diameter $>7 \mathrm{~cm}$ and slow growth $<1.5 \mathrm{~mm}$, representing the external part of mature trunks) and 4 (large diameter $>7 \mathrm{~cm}$ and fast growth $>1.5 \mathrm{~mm}$, also representing the external part of mature trunks) presented minor values in both assemblages. However, anthraco-group 2 (small diameter $<7 \mathrm{~cm}$ and fast growth $>1.5 \mathrm{~mm}$, representing both branches and/or the internal part of mature trunks) presented important values in the fallen roof level (being also present, but with inferior values, in the habitat layer). In order to distinguish if these fragments of anthraco-group 2 corresponded to internal parts of bigger trunks and/or to small branches, ring width was analysed.

The mean ring width of the charcoal fragments measured for anthraco-groups 2 and 4 in these two assemblages was well above the $1.5 \mathrm{~mm}$ threshold (around $2.5 \mathrm{~mm}$, Figure 9). This fact, together with the documentation of some fragments of anthraco-group 4 in the roof layer, suggests that trunks could have been used as firewood or as constructive timber. The fact that anthraco-group 4 is only present in the roof layer and that the values of anthraco-group 2 are higher here, suggests that trunks would have been used as construction timber, burnt after the fire event that destroyed the building, rather than as fuel (which, in the case of pine, would focus on branches).

Figure 9: Mean and whisker plot of the ring widths measured on the charcoal fragments for each anthraco-group: a) Building 51 in Ses Païsses (left: fallen roof level; right:habitat layer); b) Na

34 Galera. 
1 The anthracological assemblages of Building 25 (Ses Païsses) and Talaiot 3 (Son Fornés) present

2 different anthraco-typological results (Figure 8). Both assemblages are characterised by the 3 predominance of anthraco-groups 2 and 4. Anthraco-group 1 is also documented in both 4 assemblages, especially in Building 25. This result suggests the exploitation of both small woods 5 and larger trunks (especially with fast growth), indicating the use of all tree organs. This could 6 represent the cutting down of pines, but it is not possible to confirm that both organs came from the 7 same trees.

8 In the case of Building 25, where no fire event was detected, the anthracological assemblage 9 represents fuel consumption debris, probably linked to metallurgical activities (Aramburu 2009; 10 Picornell-Gelabert and Carrión 2017). These results suggest that Late Iron Age groups in Mallorca 11 were cutting down pines to fulfil the significant fuel demands of industrial activities, such as 12 metallurgy.

13 In the case of Talaiot 3, the presence of charcoal fragments derived from the burning of trunks also 14 represents the use of this tree as construction timber. The assemblage was generated after a fire 15 event that ended with the collapse of this monumental tower-shaped building, in which wooden 16 beams burnt down and fragmented into charcoal pieces. This indicates that during the Late Iron Age pine populations on the island would have also been affected by the cutting down of individual trees to provide timber.

19 Finally, the anthraco-typology of $\mathrm{Na}$ Galera shows a clear predominance of small diameter and slow growth fragments (anthraco-group 1, Figure 8), originating from branches. The occurrence of fragments with diameters larger than $7 \mathrm{~cm}$ and fast growth (anthraco-group 4) is minor and does not suggest relevant presence of trunks in the assemblage. However, anthraco-group 2 presents important values and could represent both branches and/or the internal part of trunks. In this case, the average ring width of the charcoal fragments from anthraco-group 2 were just slightly above 2 mm (Figure 9), so do not indicate the recurrent presence of fragments from the internal part of mature trunks, as detected in the roof layer of Building 51 in Ses Païsses (Figure 9). Accordingly, it can be suggested that most of the fragments anthraco-group 2, as well as those of the predominant anthraco-group 1, represent the use of branches. These branches would have been used to fulfil the fuel demands of the diverse activities carried out in this Late Iron Age ceremonial building. This fuel debris was then deposited in the cistern, which had been repurposed as a dump during $1^{\text {st }}$ century AD.

32 However, some of the fragments from anthraco-group 2 and a few from anthraco-group 4 may represent pieces of larger trunks. Considering that the assemblage originates from the use of a dump over a relatively long period of time (secondary position), it is difficult to assess the origin of the charcoal fragments. During the excavation of the dump, the discovery of large charcoal fragments, 
1 with a similar chronology to those of the ceremonial building, suggest that this assemblage

2 represents the debris of burnt timber removed during cleaning. Therefore, even if some of the

3 fragments derive from large trunks, they probably represent the timber elements of the building

4 destroyed by the fire (Arqueover 2016). The debris from the destruction of the main building could

5 therefore also have been discarded in the same dump. However, the fact that big articulated charcoal

6 fragments were detected during the excavation of the pit, together with the clear predominance of

7 branch exploitation attested by anthraco-typology, suggests that fuel debris was cleaned on a

8 frequent basis and that once deposited in the pit charcoal suffered little mechanical disturbance.

9 Moreover, the fact that most of the wood used is so uniform, does not allow us to rule out the use of

10 branches for the construction of specific structures (e.g. trusses, palisades, roofs). These results,

11 however, undoubtedly lead us to review the context and the initial association with timber attributed

12 to this charcoal assemblage. The evidence of metallurgical activity carried out on the Na Galera

13 islet during the Punic period (thanks to the discovery of iron slag and a foundry mold), may also

14 explain the need for fuel of a specific caliber (Guerrero 1981, 2003); but, there is no a clear

15 association with these metallurgical activities and the studied materials from the dump.

\section{5. Conclusions}

18 This study shows that the anthraco-typology approach created for temperate angiosperms with ringporous wood anatomy (Quercus petraea/robur, Dufraisse et al. 2018a) is applicable to Mediterranean gymnosperms (Pinus halepensis), provided that an appropriate dendrochronological referential is built. The combination of diverse dendro-anthracological parameters (diameter and growth) measurable with dendro-anthracological tools and the adjustment of the anthraco-typology principles to gymnosperms wood anatomy (due to the heartwood-sapwood distinction tool not being applicable) allowed us to interrogate the anthracological assemblages beyond taxonomical identification and to characterise diverse pinewood exploitation strategies.

26 The model is based in the fact that charcoal-pith distance cannot single-handedly distinguish

27 between the charcoal fragments derived from trunks or branches. Large diameter classes correspond to mature woods or trunks, but fragments with small diameter classes can stem from both branches and trunks. Radial growth has therefore been proposed as a complementary proxy to distinguish between them for the smaller diameter classes measured in an archaeological charcoal assemblage. The modern dendrochronological dataset has allowed us to i) identify differential radial growth rates for both organs of the same tree with the same cambial age; ii) prove that this is also applicable when replacing cambial age for diameter classes; iii) establish a threshold dividing slow

$34(<1.5 \mathrm{~mm})$ from fast $(>1.5 \mathrm{~mm})$ radial growth; and to iv) model differential growth rates for both branches ( $<7 \mathrm{~cm}$ diameter) and trunks ( $>7 \mathrm{~cm}$ diameter $)$. 
1 The combination of both parameters, according to the anthraco-typological principles, allowed us to

2 establish four different anthraco-groups, characterising the exploitation of trunks and branches after

3 the dendro-anthracological analysis of Aleppo pine archaeological charcoal fragments. This study,

4 therefore, confirms that the development of dendrochronological referential datasets for different

5 species and regions is needed to adapt the anthraco-typological principles to every tree species.

6 Accordingly, the application of the anthraco-groups, defined after the referential dataset, to five

7 different archaeological assemblages in which dendro-anthracological parameters were measured,

8 has allowed the different pinewood management practices in prehistoric and protohistoric sites of

9 Mallorca to be defined. In Building 51 (Ses Païsses), the dendro-anthracological analysis has

10 confirmed that, even if the assemblage was formed after a fire event that affected the entire

11 building, most of the charcoal fragments from the occupation layer correspond to branches that

12 would have been used as fuel. However, the results obtained from the roof layer highlight the

13 presence of trunk fragments that may represent the use of pine as constructive timber (burnt and

14 fragmented after the fire event). In this sense, the dendro-anthracological study suggests a possible

15 diverse origin of the pine charcoal fragments from the two different layers: one corresponding to the

16 occupation and the other to the fallen roof after the fire. This information complements the

17 interpretation of the formation of the deposit made by the excavators (differentiation in the sub-

18 layers, fallen roof and occupation layer).

19 The use of pine trunks as constructive timber seems clear during the Late Iron Age phase of Talaiot

203 in Son Fornés. Even though during the excavation of the fire destruction layers no pine beams

21 and/or other wooden architectural elements were detected, dendro-anthracological analysis of the

22 charcoal assemblage of this layer shows a clear predominance of fragments derived from the

23 burning of pine trunks.

24 A similar anthraco-typological diagram was detected in Building 25 (Ses Païsses), where evidence of metallurgical production was identified. In this case, the charcoal fragments must have originated from the use of wood as fuel, as no evidence of a fire event was detected during excavation. In this sense, the identification of charcoal fragments deriving from pine trunks suggests that the Late Iron Age populations of Mallorca cut down trees to fulfil specific energetic demands for various activities, such as metallurgical production.

30 Finally, dendro-anthracological analysis of the charcoal assemblage from the Na Galera dump allowed us to discriminate the different origins of the charcoal fragments deposited here during a relatively long period of time in the the $1^{\text {st }}$ century AD. Most of the assemblage is composed of

33 fragments deriving from small branches, used as firewood, the debris of which would have been

34 cleaned up and deposited in the dump. However, part of the assemblage could derive from larger

35 trunks, suggesting that another kind of charcoal debris was deposited in the same place. 
2 The measurement of these dendro-anthracological parameters and the treatment of the results 3 according to anthraco-typological principles, allowed us to analyse the archaeological charcoal

4 fragments beyond their taxonomical identification. The anthraco-typological characterisation of the 5 charcoal fragments of Aleppo pine enabled us to obtain valuable information to better interpret both 6 the formation of the anthracological assemblages and past human behaviour (pinewood 7 management practices). Anthraco-typology, therefore, constitutes a relevant tool to ascertain the 8 origin, homogeneous or diverse, of charcoal fragments forming an anthracological assemblage after 9 a destructive fire, where the potential burning and fragmentation of timber may occur (distinguished 10 by the presence/absence of timber and/or firewood in an assemblage), as seen in Building 51 (Ses 11 Païsses). In this case, the possibility to characterise the presence/absence of firewood and/or timber 12 remains allows us to explain the formation of the archaeological layers and identify different wood 13 uses for the same species. A similar case was described at Talaiot 3 (Son Fornés), where the 14 anthraco-typological analysis shows that timber elements were burnt down and fragmented during 15 the fire that destroyed the building.

16 Moreover, in secondary deposits, it is difficult to assess the original use (or uses) of the wood that 17 generated the charcoal fragments. In the case of the dump at $\mathrm{Na}$ Galera, anthraco-typology suggests 18 two potentially different origins for the pine charcoal fragment assemblage: firewood debris 19 deposited after the cleaning of the hearth, and charcoal fragments derived from the burnt and 20 fragmented timber from a neighbouring building destroyed by fire.

21 Finally, the anthraco-typological analysis has also allowed us to identify relevant forest 22 management practices in relation to the energetic demands of prehistoric societies, which are not 23 possible to identify solely after the taxonomical identification of charcoal fragments. In Building 25 24 (Ses Païsses), where evidence of metallurgical activity was detected, a recurrent use of pine trunks as firewood was identified. This suggests that, during the Late Iron Age, the specific fuel demand generated by industrial activities, such as metalworking, would often lead to the cutting down of pine trees to provide firewood. Identifying the forest management practices of prehistoric societies enlarges the scope of the charcoal record regarding socio-environmental practices, natural resources management and human impact on forest ecosystems.

30 Finally, it is important to note that after dendrochronological reference datasets and the testing of applicability of anthraco-typology, further studies look to improve the interrogation of the anthracological record. The development of dendro-anthracological datasets will allow us to

33 interrogate the impact of wood exploitation on past woodlands and offer new insights to identify 34 more suitable fragments for anthraco-climatic analyses (or select the most reliable charcoal 35 fragments for isotopic analysis) contributing to the future development of archaeological wood 
charcoal analysis.

\section{Acknowledgements}

5 This work was supported by the Spanish Ministry of Science, Innovation and Universities [project

6 'HAR2015-67211-P: Archipiélagos: Paisajes, comunidades prehistóricas insulares y estrategias de 7 conectividad en el Mediterráneo Occidental. El caso de las Islas Baleares durante la Prehistoria' of 8 the ArqueoUIB research group; research project 'HAR2017-83656P: La acción humana como 9 agente transformador del paisaje: análisis de macrorrestos vegetales en las cuatro grandes islas de 10 Baleares' of the PREMEDOC team; and the Juan de la Cierva Incorporación grant for Llorenç 11 Picornell-Gelabert (IJCI-2015_24550)] and the Agence Nationale de la Recherche [DENDRAC 12 project].

13 The authors are grateful to the following people who provided help during the development of the 14 research: Carles V. Cardona Ametller (IBANAT - Institut Balear de la Natura, Conselleria de Medi 15 Ambient i Territori, Government of the Balearic Islands) provided help during fieldwork; Klemen 16 Novak (Department of Wood Science and Technology, Biotechnical Faculty, University of 17 Ljubljana) provided help during dendrochronological samples treatment and measurement; Marta 18 Alcolea (University of Santiago de Compostela) provided help during data treatment for the 19 referential analysis and for the design of figure 3; Sylvie Coubray (INRAP-UMR7209) participated 20 in the anthraco-typological discussion and helped design figure 2; Alejandra Galmès (University of 21 the Balearic Islands) drew figure 1; and Jordi Navarro (Temabcn) helped draw figure 2. We are also 22 grateful to the editors and two anonymous reviewers who helped us improving the paper.

\section{$\underline{\text { References }}$}

Aramburu, J. 2009. Ses Païsses (Artà, Mallorca). Excavaciones en el Edificio 25 ("Climent

27 Garau”). Campañas 2004, 2005 y 2006. Palma: author's edition. 28 https://www.academia.edu/20195097/Ses_Pa\%C3\%AFsses_Art\%C3\%A0_Mallorca_Excavaciones _en_el_edificio_25

30 Arqueover 2016. Informe de la campaña de excavación arqueológica en el islote de Na Galera,

31 Palma. Excavation report available at:

32 https://nagalerapunica.files.wordpress.com/2016/08/memoria-2015_1parte.pdf. Last access 28 may 332020.

34 Asouti, E. and Austin, P. 2005. Reconstructing woodland vegetation and its exploitation by past 
1 societies, based on the analysis and interpretation of archaeological wood charcoal macroremains.

2 Environmental Archaeology 10: 1-18. DOI: https://doi.org/10.1179/env.2005.10.1.1

3 Burjachs, F., Pérez-Obiol, R., Picornell-Gelabert, Ll., Revelles, J., Servera-Vives, G., Expósito, I., 4 and Yll, E.-I. 2017. Overview of Environmental Changes and Human Colonization in the Balearic 5 Islands (Western Mediterranean) and Their Impacts on Vegetation Composition During the

6 Holocene. Journal of Archaeological Science: Reports 12: 845-859. DOI:

7 https://doi.org/10.1016/j.jasrep.2016.09.018

8 Chabal, L., Fabre, L., Terral, J.F. and Théry-Parisot, I. 1999. L'anthracologie. In A. Ferdière (ed.), 9 La Botanique. Paris: Eds. Errance, p. 43-104.

10 Coubray, S. and Dufraisse A. 2019. De l'arbre à la forêt domestiquée : pratiques de gestion et 11 systèmes agroforestiers. Application de l'anthraco-typologie sur des sites néolithiques du Nord de la 12 France et du pourtour de l'arc alpin. In C. Montoya, J.-P. Fagnart and J.-L. Locht (dir.), Préhistoire 13 de l'Europe du Nord-Ouest. Mobilités, climats et identités culturelles, actes du $27^{\mathrm{e}}$ congrès 14 préhistorique de France (Amiens, 30 mai-4 juin 2016), vol. 3. Paris: Société préhistorique française, 15 p. $139-159$.

16 Deleuze, C., Monreau, F., Renaud, J.P., Vivien, Y., Rivoire, M., Santenoise, Ph., Longuetaud, F., 17 Mothe, F., Herve, J.C., and Vallet, P. 2014. Estimer le volume total d'un arbre, quelles que soient 18 l'essence, la taille, la sylviculture, la station. RDV Tech. ONF 44: 22-32.

19 de Luis, M., Čufar, K., di Filippo, A, Novak, K., Papadopoulos, A., Piovesan, G., Rathgeber, C. 20 B.K., Raventós, J., Saz, M.A., Smith, K.T. 2013. Plasticity in Dendroclimatic Response across the 21 Distribution Range of Aleppo Pine (Pinus halepensis). PLoS ONE 8(12): e83550.

22 Dufraisse A. 2006. Charcoal anatomy potential, wood diameter and radial growth. In A. Dufraisse 23 (ed.), Charcoal analysis: new analytical tools and methods for archaeology. Papers from the table24 ronde held in Basel (October 2004). Oxford: Archaeopress, BAR International Series, p. 47-61.

25 Dufraisse, A. 2008. Firewood management and woodland exploitation during the late Neolithic at Lac de Chalain (Jura, France). Vegetation History and Archaeobotany 17: 199-210.

Dufraisse, A. 2012. Firewood and woodland management in their social, economic and ecological dimensions. New perspectives. In: Badal, E., Carrion, Y., Grau, E., Macías, M., Ntinou, M. (Eds.), 
1 Dufraisse, A., Pétrequin, A.M. and Pétrequin, P. 2007. La gestion du bois de feu: un indicateur des

2 contextes socio-écologiques. Approche ethnoarcheologique dans les Hautes Terres de Papua

3 (Nouvelle-Guinée indonésienne). In M. Besse (ed.) Sociétés néolithiques. Des faits archéologiques

4 aux fonc-tionnements socio-économiques. Actes du 27 e colloque inte-rrégional sur le Néolithique

5 (Neuchâtel, octobre 2005). Lausanne : Cahiers d'archéologie romande, vol. 108, p. 115-126.

6 Dufraisse, A., Garcia Martinez, M.S., 2011a. Mesurer les diametres du bois de feu en anthracologie.

7 Outils dendrometriques et interpretation des donnees. Anthropobotanica 2: 1-18.

8 Dufraisse A., Coubray S., Girardclos O., Nocus N., Lemoine M., Dupouey J.-L., and Marguerie, D. 9 2018a. Anthraco-typology as a key approach to past firewood exploitation and woodland 10 management reconstructions. Dendrological reference dataset modelling with dendro11 anthracological tools, Quaternary International 463 (Part B): 232-249. DOI : 12 10.1016/j.quaint.2017.03.065.

13 Dufraisse, A., Coubray, S., Girardclos, O., Dupin, A., and Lemoine, M., 2018b. Contribution of tyloses quantification in earlywood oak vessels to archaeological charcoal analyses: Estimation of a minimum age andinfluences of physiological and environmental factors. Quaternary International 463 (Part B): 250-257. DOI: https://doi.org/10.1016/j.quaint.2017.03.070

Dufraisse, A., and Coubray, S. 2018. De 1'arbre à la forêt domestiquée : apport de l'anthracotypologie. Les nouvelles de l'archéologie: 152: 1-13. DOI : 10.4000/nda.4533

Dufraisse. A., Bardin, J., Picornell-Gelabert, L1., Coubray, S., García-Martínez, M.S., Lemoine, M., and Vila Moreiras, S. 2019. Pith location tool and wood diameter estimation: Validity and limits tested $\mathrm{T}$ on seven taxa to approach the length of the missing radius on archaeological wood and charcoal fragments. Journal of Archaeological Science: Reports 29: 102166. DOI:

23 https://doi.org/10.1016/j.jasrep.2019.102166

24 Garcia Martinez M.S. and Dufraisse A. 2011. Bronze Age firewood exploitation in south eastern Iberia : a study focusing on wood diameter estimation. In E. Badal, Y. Carrion, E. Grau, M. Garcia, M. Ntinou (eds), Ve International Meeting of charcoal analysis. The charcoal as cultural and biological heritage. Saguntum extra 11:187-188.

Gaudin, S., 1996. Dendrometrie des peuplements. BTSA Besançon: Gestion Forestiere.

29 Gil L., Manuel C., and Díaz, P. 2003. La transformación histórica del paisaje forestal en las islas 
1 Goubitz S., Werger M., and Ne'eman, G. 2003. Germination response to fire-related factors of seeds

2 from non-serotinous and serotinous cones. Plant Ecology 169: 195-204. DOI:

3 https://doi.org/10.1023/A:1026036332277

4 Guerrero, V. M. 1981. Los asentamientos humanos sobre los islotes costeros de Mallorca. BSAL 38:

5 192-131.

6 Guerrero, V. M. 2003. Colonos e indígenas en las Baleares prerromanas. In XVIII Jornades

7 d'Arqueologia Feníncio - Púnica. L'impacte fenício-púnic en les societats autòctones. Eivissa, del

824 al 28 de novembre de 2003. Treballs del Museu Arqueològic d'Eivissa i Formentera, 54, pp. 1459203.

10 Haneca, K., Van Acker, J., and Beeckman, H., 2005. Growth trends reveal the forest structure

11 during Roman and Medieval times in Western Europe: a comparison between archaeological and

12 actual oak ring series (Quercus robur and Quercus petraea). Annals of Forest Science 62 (8): 797 -

13 805. DOI: 10.1051/forest:2005085

14 Holmes, R. 1994. Dendrochronology program library user's manual. Laboratory of Tree-Ring

15 Research, University of Arizona, Tucson, USA.

16 Larsson, L.A. 2003. COORECORDER v2.3.13: Image Co-ordinate Recording Program. Available 17 online at http://www.cybis.se.

18 Llorens L., Gil Ll., and Tébar FJ. 2007. La vegetació de l'illa de Mallorca. Palma: Agència Balear 19 de l'Aigua I la Qualitat Ambiental.

20 Marguerie, D., Hunot, J.-Y. 2007. Charcoal analysis and dendrology: data from archae- ological 21 sites in western France. Journal of Archaeological Science 34 (9), 1417-1433. DOI: https://doi.org/ 22 10.1016/j.jas.2006.10.032.

23 Ne'eman G., Goubitz S. and Nathan R. 2004. Reproductive traits of Pinus halepensis in the light of 24 fire - a critical review. Plant Ecology 171: 69-79.

25 Picornell-Gelabert, Ll. 2009. Antracología y Etnoarqueología. Perspectivas para el estudio de las 26 relaciones entre las so- ciedades humanas y su entorno. Complutum 20 (1): 133-151.

27 Picornell-Gelabert, Ll. 2012. Paisaje vegetal y sociedades prehistóricas y protohistóricas en 28 Mallorca y Menorca: Una aproximación desde la antracología. PhD diss., Universitat de 
1 Barcelona.

2 Picornell-Gelabert, Ll. 2017. Etnoarqueología del combustible: Una aproximación arqueológica a

3 las interacciones sociales entre bosques, árboles y personas. Complutum 28(2): 325-339. DOI:

4 http://dx.doi.org/10.5209/CMPL.58433

5 Picornell-Gelabert, L1, and Y. Carrión Marco. 2017. Landscape and Firewood Procurement at the

6 Prehistoric and Protohistoric Site of Ses Païsses (Island of Mallorca, Western Mediterranean).

7 Quaternary International 458: 56-74. DOI: https://doi.org/10.1016/j.quaint.2017.03.018

8 Picornell-Gelabert, Ll, and G. Servera-Vives. 2017. Landscape Practices and Everyday Life in

9 Domestic Spaces in Bronze Age Mallorca (Balearic Islands): Perspectives for and Archaeology of 10 Fuel and Firewood. Quaternary International 431: 73-89. DOI:

11 https://doi.org/10.1016/j.quaint.2015.12.058

12 Picornell-Gelabert, Ll. and Dufraisse, A. 2018. Wood for Building: Woodland Exploitation for 13 Timber Procurement in the Prehistoric and Protohistoric Balearic Islands (Mallorca and Menorca; 14 Western Mediterranean). Environmental Archaeology. DOI:

15 https://www.tandfonline.com/doi/full/10.1080/14614103.2018.1521086

16 Piqué, R. and Noguera, M. 2002. Landscape and management of forest resources in the Balearic 17 Islands during the II-I millennium BC. In W. Waldren and J. Ensenyat (eds.) World Islands in 18 prehistory. International insular investigations. Oxford: Archaeopress BAR I.S., p. 292-300.

19 Servera-Vives, G., Riera,S., Picornell-Gelabert, L1., Moffa-Sánchez, P., Llergo, Y., Garcia, A., Mus 20 Amezquita, M.,García, S. and Calvo, M. 2018. The Onset of Islandscapes in the Balearic Islands: A 21 Study-Case of Addaia (Northern Minorca, Spain). Palaeogeography, Palaeoclimatology, 22 Palaeocology 498(1): 9-23. DOI: https://doi.org/10.1016/j.palaeo.2018.02.015

23 Théry-Parisot, I., Chabal, L. and Chrzavzez, J., 2010. Anthracology and taphonomy, from wood 24 gathering to charcoal analysis. A review of the taphonomic processes modifying charcoal 25 assemblages, in archaeological contexts. Palaeogeography, Palaeoclimatology, Palaeoecology 291 26 (1-2): 142-153. DOI: https://doi.org/10.1016/j.palaeo.2009.09.016 


\begin{tabular}{|c|c|c|c|c|c|c|c|c|c|c|c|c|c|c|}
\hline \multirow[t]{2}{*}{ Site } & \multicolumn{2}{|c|}{ Location } & & \multirow{2}{*}{$\begin{array}{l}\text { Altitu } \\
\text { de } \\
\text { m.a.s.l }\end{array}$} & \multirow{2}{*}{\begin{tabular}{|l}
$\begin{array}{l}\text { Slope } \\
\text { and } \\
\text { orientati } \\
\text { on }\end{array}$ \\
\end{tabular}} & \multirow[t]{2}{*}{ Bioclimatology } & \multirow{2}{*}{\begin{tabular}{|l|}
$\begin{array}{l}\text { Average } \\
\text { annual } \\
\text { precipitati } \\
\text { on (ml) }\end{array}$ \\
$\begin{array}{l}\text { Average an } \\
\text { precipitatio }\end{array}$
\end{tabular}} & \multirow{2}{*}{\begin{tabular}{|l}
$\begin{array}{l}\text { Forest } \\
\text { formation }\end{array}$ \\
nual \\
n (ml)
\end{tabular}} & \multicolumn{3}{|c|}{ Trees sampled } & \multicolumn{3}{|c|}{$\begin{array}{c}\text { Average diameter (with standard } \\
\text { deviation) }\end{array}$} \\
\hline & $\begin{array}{c}\text { Quadr } \\
\text { ant }\end{array}$ & $\mathbf{X}$ & $\mathbf{Y}$ & & & & & & \begin{tabular}{|l|} 
Trun \\
ks \\
only
\end{tabular} & \begin{tabular}{|l|} 
Trunks \\
+ \\
branche \\
s
\end{tabular} & $\begin{array}{l}\text { Period } \\
\text { repres } \\
\text { ented }\end{array}$ & $\begin{array}{l}\text { Averag } \\
\text { e tree's } \\
\text { age }\end{array}$ & $\begin{array}{l}\text { Trunks: Average } \\
\text { diameter at breast } \\
\text { height (DBH) }\end{array}$ & $\begin{array}{l}\text { Branches: average } \\
\text { diameter for small, } \\
\text { medium and large } \\
\text { samples }\end{array}$ \\
\hline Caimari & $31 \mathrm{~S}$ & $\begin{array}{c}49076 \\
4\end{array}$ & $\begin{array}{c}44042 \\
19\end{array}$ & $\begin{array}{r}324- \\
370\end{array}$ & Flat & $\begin{array}{l}\text { Messomediterra } \\
\text { nean subhumid }\end{array}$ & 696 & \begin{tabular}{|l} 
Aleppo pine and \\
holm oak \\
(Quercus ilex) \\
forest \\
colonizing \\
ancient olive \\
terraces \\
\end{tabular} & 13 & 5 & $\begin{array}{l}1888- \\
2017\end{array}$ & 84,7 & $37,9(12,9) \mathrm{cm}$ & $\begin{array}{l}\text { Small: } 1,6(0,7) \mathrm{cm} / \\
\text { Medium: } 2,9(0,9) \mathrm{cm} \\
\text { / Large: } 6,0(1,6) \mathrm{cm}\end{array}$ \\
\hline Binissalem & $31 \mathrm{~S}$ & \begin{tabular}{c|}
48785 \\
6
\end{tabular} & $\begin{array}{c}43929 \\
04\end{array}$ & $\begin{array}{r}120- \\
147\end{array}$ & Flat & $\begin{array}{l}\text { Thermomediterr } \\
\text { anean dry }\end{array}$ & 440 & $\begin{array}{l}\text { Aleppo pine } \\
\text { plantation }\end{array}$ & 13 & 0 & $\begin{array}{ll}1914- \\
2011\end{array}$ & 88,2 & $38,0(7,0) \mathrm{cm}$ & No branches sampled \\
\hline Cap Salines & $31 \mathrm{~S}$ & \begin{tabular}{|c|}
50466 \\
2
\end{tabular} & $\begin{array}{c}43463 \\
60\end{array}$ & $8-12$ & Flat & $\begin{array}{l}\text { Thermomediterr } \\
\text { anean semiarid }\end{array}$ & 236 & $\begin{array}{l}\text { Coastal macchia } \\
\text { with pine and } \\
\text { Phoenicean } \\
\text { juniper } \\
\text { (Juniperus } \\
\text { phoenicea) } \\
\end{array}$ & 12 & 5 & $\begin{array}{l}1890- \\
2017\end{array}$ & 106,6 & $24,3(5,3) \mathrm{cm}$ & $\begin{array}{l}\text { Small: } 1,3(0,2) \mathrm{cm} / \\
\text { Medium: } 2,9(0,8) \mathrm{cm} \\
\text { / Large: } 5,6(0,9) \mathrm{cm}\end{array}$ \\
\hline \begin{tabular}{|l} 
Comuna \\
Lloret
\end{tabular} & $31 \mathrm{~S}$ & $\begin{array}{c}49662 \\
6\end{array}$ & $\begin{array}{c}43852 \\
22\end{array}$ & $\begin{array}{r}139- \\
142\end{array}$ & Flat & $\begin{array}{l}\text { Thermomediterr } \\
\text { anean dry }\end{array}$ & 487 & $\begin{array}{l}\text { Macchia with } \\
\text { Aleppo pine }\end{array}$ & 0 & 5 & $\begin{array}{l}1972- \\
2017\end{array}$ & 40,6 & $30,7(6,9) \mathrm{cm}$ & \begin{tabular}{|l|} 
Small: $1,1(0,3) \mathrm{cm} /$ \\
Medium: $2,8(0,7) \mathrm{cm}$ \\
/ Large: $5,6(0,8) \mathrm{cm}$
\end{tabular} \\
\hline
\end{tabular}

Table 1: Description of the forest stations sampled for the referential dendrological study 


\begin{tabular}{|c|c|c|c|c|c|c|c|c|c|c|c|c|c|}
\hline Sample name & Site & Type of site & Building & Chronology & $\begin{array}{l}\text { Type of } \\
\text { building }\end{array}$ & $\begin{array}{l}\text { Type of } \\
\text { assemblage }\end{array}$ & $\begin{array}{l}\text { Archaeological } \\
\text { context }\end{array}$ & $\begin{array}{l}\text { Abandonment } \\
\text { after a fire } \\
\text { event }\end{array}$ & $\begin{array}{l}\text { Total } n^{0} \text { of } \\
\text { fragments } \\
\text { identified }\end{array}$ & $\begin{array}{l}\mathrm{N}^{\circ} \text { of Pinus } \\
\text { halepensis } \\
\text { fragments } \\
\text { identified }\end{array}$ & $\begin{array}{l}\mathrm{N}^{0} \text { of } \\
\text { fragments } \\
\text { measured }\end{array}$ & $\begin{array}{l}\mathrm{N}^{\circ} \text { of rings } \\
\text { measured }\end{array}$ & References \\
\hline $\begin{array}{l}\text { Ses Païsses } 51 \\
\text { - Roof }\end{array}$ & Ses Païsses & Village & 51, Phase 2 & $\begin{array}{l}1000-850 \mathrm{cal} . \\
\mathrm{BC}\end{array}$ & $\begin{array}{l}\text { Small building } \\
\text { attached to the } \\
\text { central } \\
\text { turriform of } \\
\text { the site }\end{array}$ & $\begin{array}{l}\text { Dispersed } \\
\text { charcoal } \\
\text { fragments }\end{array}$ & $\begin{array}{l}\text { Layer } \\
\text { corresponding to } \\
\text { the fallen roof of } \\
\text { the building after } \\
\text { a fire event }\end{array}$ & Yes & & $\begin{array}{l}221 \\
\text { (corresponding } \\
\text { to the } 38,91 \% \\
\text { of the total } \\
8 \text { assemblage) }\end{array}$ & 109 & & 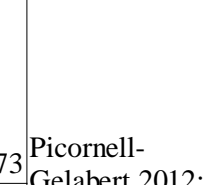 \\
\hline $\begin{array}{l}\text { Ses Païsses } 51 \\
\text { - Roof }\end{array}$ & Ses Païsses & Village & 51, Phase 2 & $\begin{array}{l}1000-850 \mathrm{cal} . \\
\text { BC }\end{array}$ & $\begin{array}{l}\text { Small building } \\
\text { attached to the } \\
\text { central } \\
\text { turriform of } \\
\text { the site }\end{array}$ & $\begin{array}{l}\text { Dispersed } \\
\text { charcoal } \\
\text { fragments }\end{array}$ & $\begin{array}{l}\text { Layer } \\
\text { corresponding to } \\
\text { the occupation of } \\
\text { the building } \\
\text { during this phase }\end{array}$ & Yes & 243 & $\begin{array}{l}85 \\
\text { (corresponding } \\
\text { to the } 34,98 \% \\
\text { of the total } \\
3 \text { assemblage) }\end{array}$ & 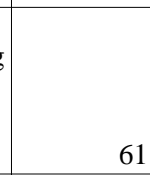 & 31 & $\begin{array}{l}\text { Picornell- } \\
\text { Gelabert and } \\
\text { Carrión Marco } \\
2017\end{array}$ \\
\hline Ses Païsses 25 & Ses Païsses & Village & 25, Phase 2 & $\begin{array}{l}350-200 \text { cal. } \\
\text { BC }\end{array}$ & $\begin{array}{l}\text { Domestic } \\
\text { building with } \\
\text { evidences of } \\
\text { metalworking }\end{array}$ & $\begin{array}{l}\text { Dispersed } \\
\text { charcoal } \\
\text { fragments }\end{array}$ & $\begin{array}{l}\text { Layer } \\
\text { corresponding to } \\
\text { the occupation of } \\
\text { the building } \\
\text { during this phase }\end{array}$ & No & 1202 & $\begin{array}{l}216 \\
\text { (corresponding } \\
\text { to the } 17,97 \% \\
\text { of the total } \\
2 \text { assemblage) }\end{array}$ & 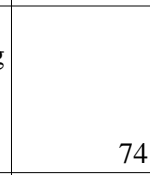 & 13 & 35 \\
\hline $\begin{array}{l}\text { Son Fornés } \\
\text { Talaiot } 3\end{array}$ & Son Fornés & Village & Talaiot 3 & $\begin{array}{l}\text { IV-III century } \\
\text { BC }\end{array}$ & $\begin{array}{l}\text { Megalithic } \\
\text { tower-shaped } \\
\text { building of } \\
\text { ceremonial } \\
\text { public use }\end{array}$ & $\begin{array}{l}\text { Dispersed } \\
\text { charcoal } \\
\text { fragments }\end{array}$ & $\begin{array}{l}\text { Layer } \\
\text { corresponding to } \\
\text { the last use and } \\
\text { collapse of the } \\
\text { building }\end{array}$ & Yes & 1579 & $\begin{array}{l}201 \\
\text { (corresponding } \\
\text { to the } 12,73 \% \\
\text { of the total } \\
9 \text { assemblage) }\end{array}$ & 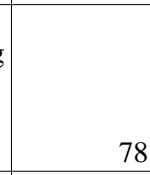 & & $\begin{array}{l}\text { Picornell- } \\
\text { Gelabert 2012; } \\
\text { Picornell- } \\
\text { Gelabert and } \\
\text { 74 Dufraisse } 2018\end{array}$ \\
\hline Na Galera & $\mathrm{Na}$ Galera & $\begin{array}{l}\text { Ceremonial } \\
\text { complex in an } \\
\text { small isled in } \\
\text { front of the } \\
\text { seachore of } \\
\text { Mallorca }\end{array}$ & $\begin{array}{l}\text { Cistern } \\
\text { (EU160) }\end{array}$ & $\begin{array}{l}1^{\text {st }} \text { Century } \\
A D\end{array}$ & $\begin{array}{l}\text { Cistern } \\
\text { attached to a } \\
\text { ceremonial } \\
\text { building }\end{array}$ & $\begin{array}{l}\text { Secondary } \\
\text { deposition of } \\
\text { charcoal } \\
\text { fragments }\end{array}$ & $\begin{array}{l}\text { Cistern reused as } \\
\text { dump pith }\end{array}$ & No & & $\begin{array}{l}119 \\
\text { (corresponding } \\
\text { to the } 36,17 \% \\
\text { of the total } \\
9 \text { assemblage) }\end{array}$ & 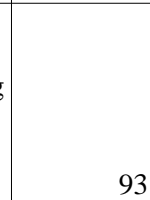 & & 04 This study \\
\hline
\end{tabular}

Table 2: Description of the archaeological charcoal assemblages analysed 


\begin{tabular}{|c|c|c|c|c|c|c|c|c|c|c|c|c|c|c|c|}
\hline \multirow{3}{*}{\begin{tabular}{|l|}
\multicolumn{1}{|c|}{ PITH- } \\
LOCATION \\
$\quad$ TOOL \\
Dalculated \\
diameter \\
classes
\end{tabular}} & \multirow{2}{*}{\multicolumn{3}{|c|}{$\begin{array}{c}\text { Galera } \\
\text { SU160 }\end{array}$}} & \multicolumn{9}{|c|}{ Ses Païsses } & \multirow{2}{*}{\multicolumn{3}{|c|}{$\frac{\text { S. Fornés }}{\text { Talaiot } 3}$}} \\
\hline & & & & \multicolumn{3}{|c|}{ 51-Roof } & \multicolumn{3}{|c|}{ 51-Habitat } & \multicolumn{3}{|c|}{ Ed. 25} & & & \\
\hline & n & $\%$ & $\%$ Admodel & n & $\%$ & $\%$ Admodel & n & $\%$ & $\%$ Admodel & n & $\%$ & $\%$ Admodel & $\mathrm{n}$ & $\%$ & $\%$ Admodel \\
\hline 1 _] $0-2] \mathrm{cm}$ & 36.00 & 38.71 & 23.88 & 34.00 & 31.19 & 17.17 & 13.00 & 21.31 & 3.57 & 11.00 & 14.86 & 3.74 & 7.00 & 8.97 & 0.00 \\
\hline$\frac{-1}{2-4]} \mathrm{cm}$ & 41.00 & 44.09 & 52.74 & 46.00 & 42.20 & 47.47 & 32.00 & 52.46 & 59.69 & 25.00 & 33.78 & 29.95 & 22.00 & 28.21 & 24.04 \\
\hline $\left.3 \_14-7\right] \mathrm{cm}$ & 11.00 & 11.83 & 14.43 & 20.00 & 18.35 & 22.73 & 14.00 & 22.95 & 33.16 & 26.00 & 35.14 & 47.59 & 25.00 & 32.05 & 33.33 \\
\hline $4+77-10] \mathrm{cm}$ & 3.00 & 3.23 & 4.98 & 5.00 & 4.59 & 7.07 & 1.00 & 1.64 & 1.53 & 6.00 & 8.11 & 10.70 & 14.00 & 17.95 & 29.51 \\
\hline 5 __]10-14] cm & 1.00 & 1.08 & 1.99 & 2.00 & 1.83 & 2.02 & 1.00 & 1.64 & 2.04 & 4.00 & 5.41 & 2.14 & 6.00 & 7.69 & 2.19 \\
\hline 6_]14-20] cm & 1.00 & 1.08 & 1.99 & 2.00 & 1.83 & 3.54 & 0.00 & 0.00 & 0.00 & 2.00 & 2.70 & 5.88 & 4.00 & 5.13 & 10.93 \\
\hline 7$]>20 \mathrm{~cm}$ & 0.00 & 0.00 & 0.00 & 0.00 & 0.00 & 0.00 & 0.00 & 0.00 & 0.00 & 0.00 & 0.00 & 0.00 & 0.00 & 0.00 & 0.00 \\
\hline Total & 93.00 & 100.00 & 100.00 & 109.00 & 100.00 & 100.00 & 61.00 & 100.00 & 100.00 & 74.00 & 100.00 & 100.00 & 78.00 & 100.00 & $\overline{100.00}$ \\
\hline
\end{tabular}

Table 3: Results of the charcoal-pith distance measurements expressed by diameter classes and modelled according to the ADmodel.

\begin{tabular}{|c|c|c|c|c|c|c|c|c|c|c|}
\hline \multirow{3}{*}{$\begin{array}{l}\text { Anthraco- } \\
\text { group }\end{array}$} & \multirow{2}{*}{\multicolumn{2}{|c|}{\begin{tabular}{|l|} 
Galera \\
SU160 \\
\end{tabular}}} & \multicolumn{6}{|c|}{ Ses Païsses } & \multirow{2}{*}{\multicolumn{2}{|c|}{\begin{tabular}{|l|} 
Son Fornés \\
Talaiot 3 \\
\end{tabular}}} \\
\hline & & & 51-Ro & & 51-H & Iabitat & Ed. 2 & & & \\
\hline & $\mathbf{n}$ & $\%$ & n & $\%$ & n & $\%$ & n & $\%$ & n & $\%$ \\
\hline 1 & 58 & 62.37 & 53 & 48.62 & 44 & 72.13 & 16 & 21.62 & 10 & 12.82 \\
\hline 2 & 30 & 32.26 & 47 & 43.12 & 15 & 24.59 & 46 & 62.16 & 44 & 56.41 \\
\hline 3 & 1 & 1.08 & 4 & 3.67 & 2 & 3.28 & 2 & 2.70 & 6 & 7.69 \\
\hline 4 & 4 & 4.30 & 5 & 4.59 & & 0 & 10 & 13.51 & 18 & 23.08 \\
\hline Total frags. & 93 & 100 & 109 & 100 & 61 & 100 & 74 & 100 & 78 & 100 \\
\hline
\end{tabular}

Table 4: Results of the dendro-anthracological parameters measured on Aleppo pine archaeological charcoal assemblages (projected diameter classes and average ring width) according to anthraco-typology principles. 


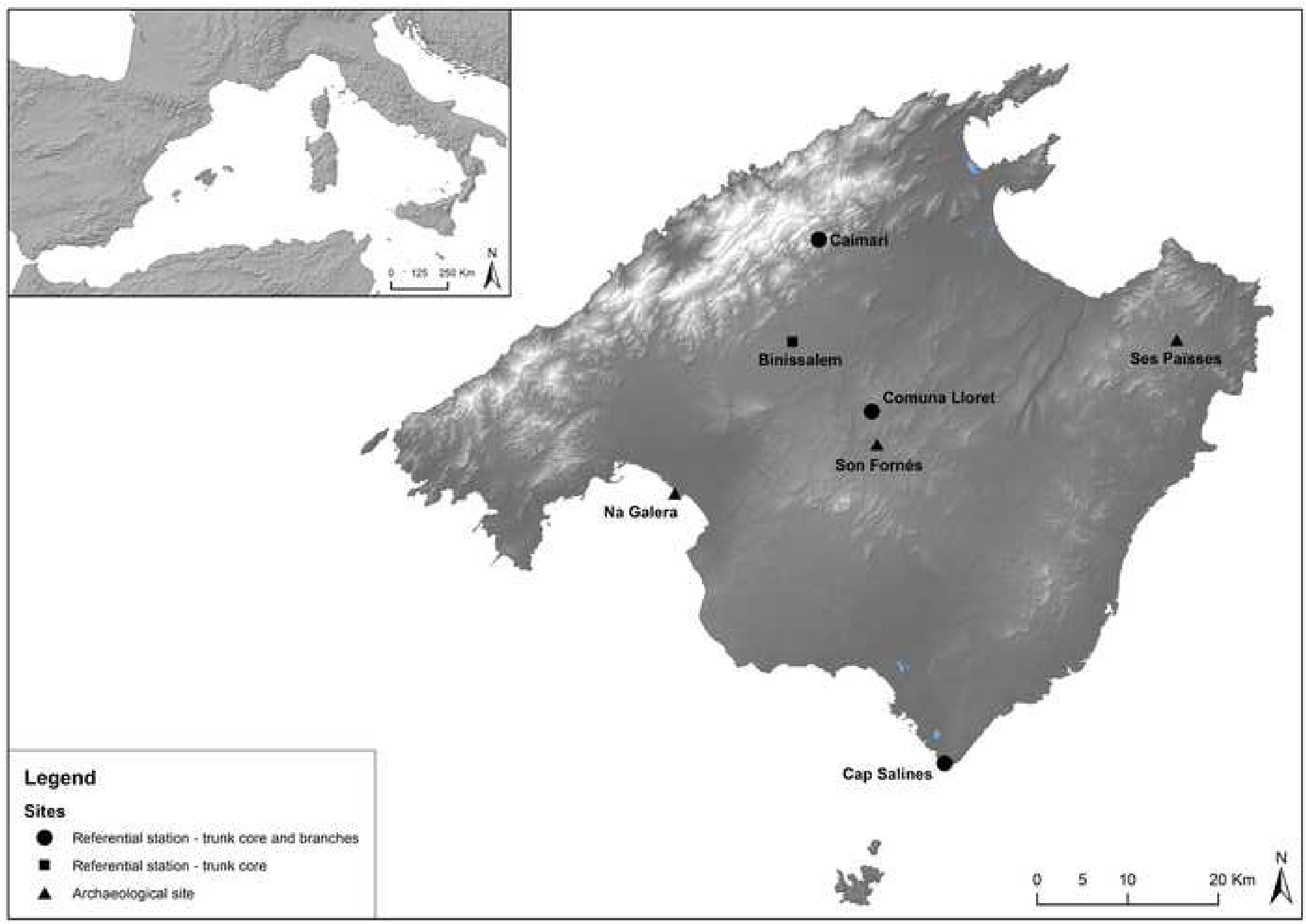




\section{DENDRO-ANTHRACOLOGICAL PARAMETERS AND TOOLS}

Dendro-anthracological parameters

Charcoal-pith distance

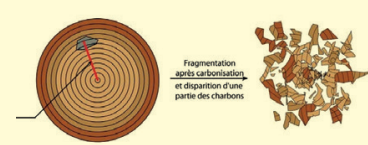

Radial growth

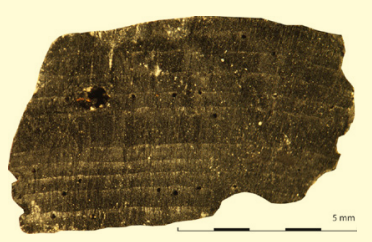

Morpho-anatomical critera

Tool

Distance and angle

between ligneous rays

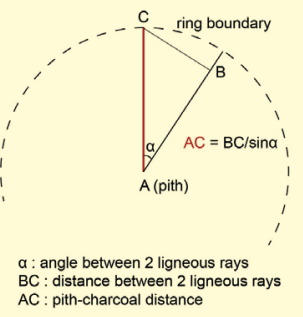

Tree-ring width

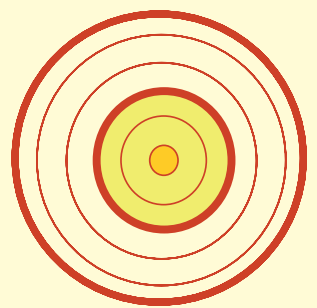

Numerical and graphic expression

Image analysis Macroscope
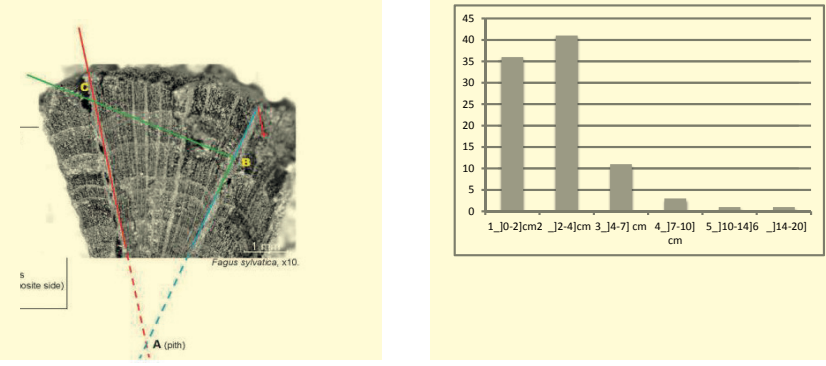

Image analysis Macroscope
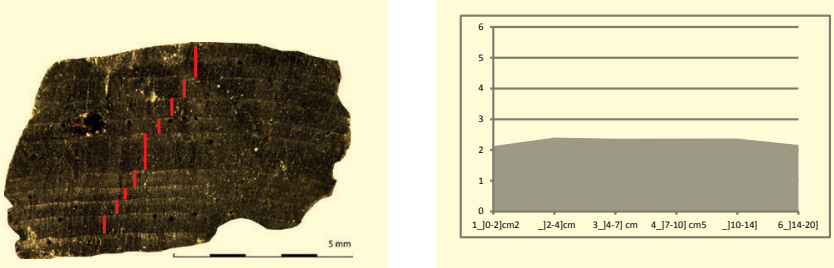

COMBINED ANALYSIS OF DENDRO-ANTHRACOLOGICAL PARAMETERS

ANTHRACO-TYPOLOGY

Dendro-anthracological parameters and criteria

Charcoal-pith distance

Diameter estimation
Data organization and interpration

Diameter classes

Based on foresters

systematisation

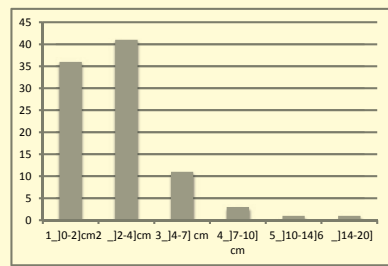

Radial growth Tree-ring width
Fast and slow grouth Based on referential model

\section{Combination of parametrs \\ Graphic expression}

\section{Anthraco-groups}

Diameter and ring width

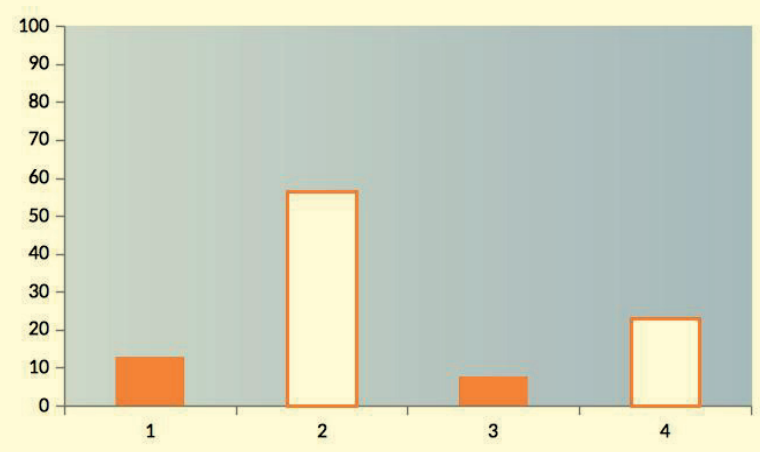




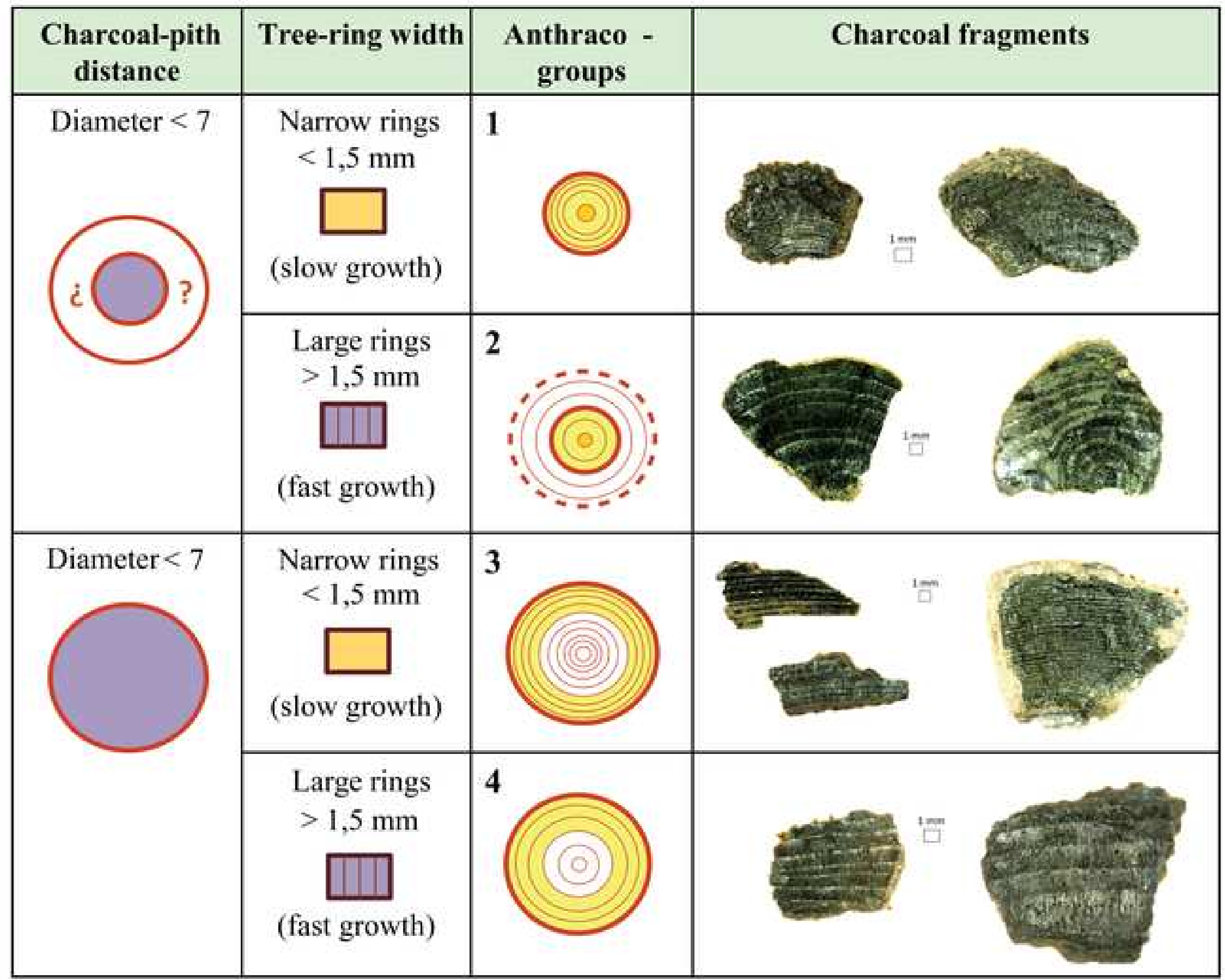



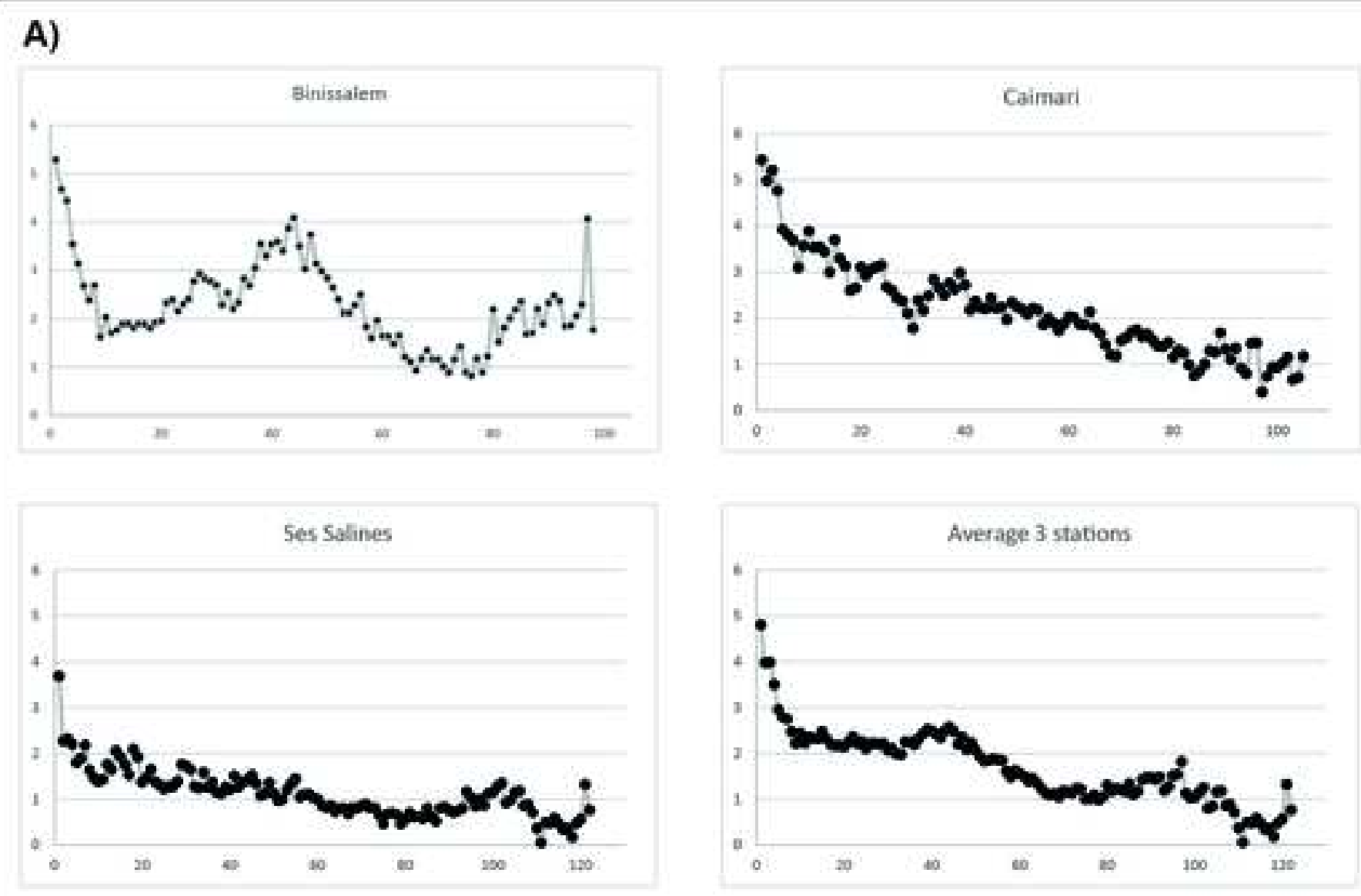

B)
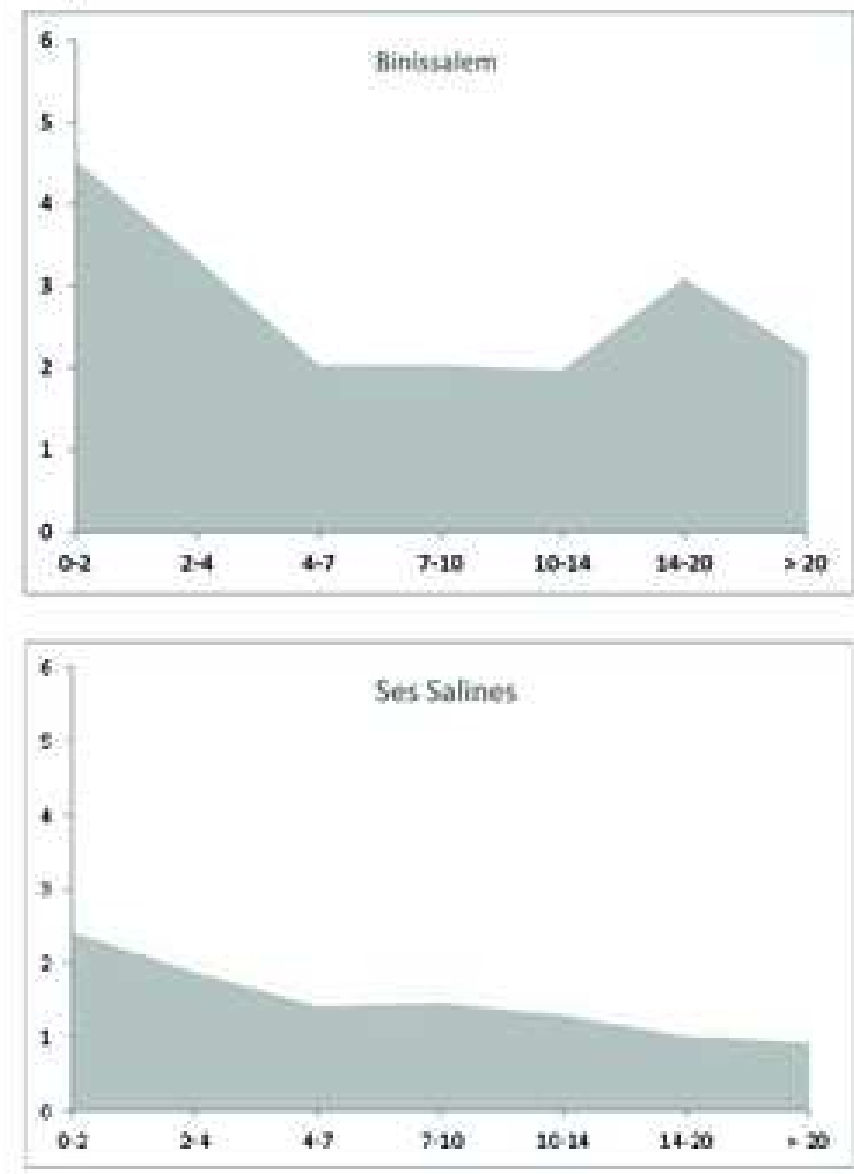
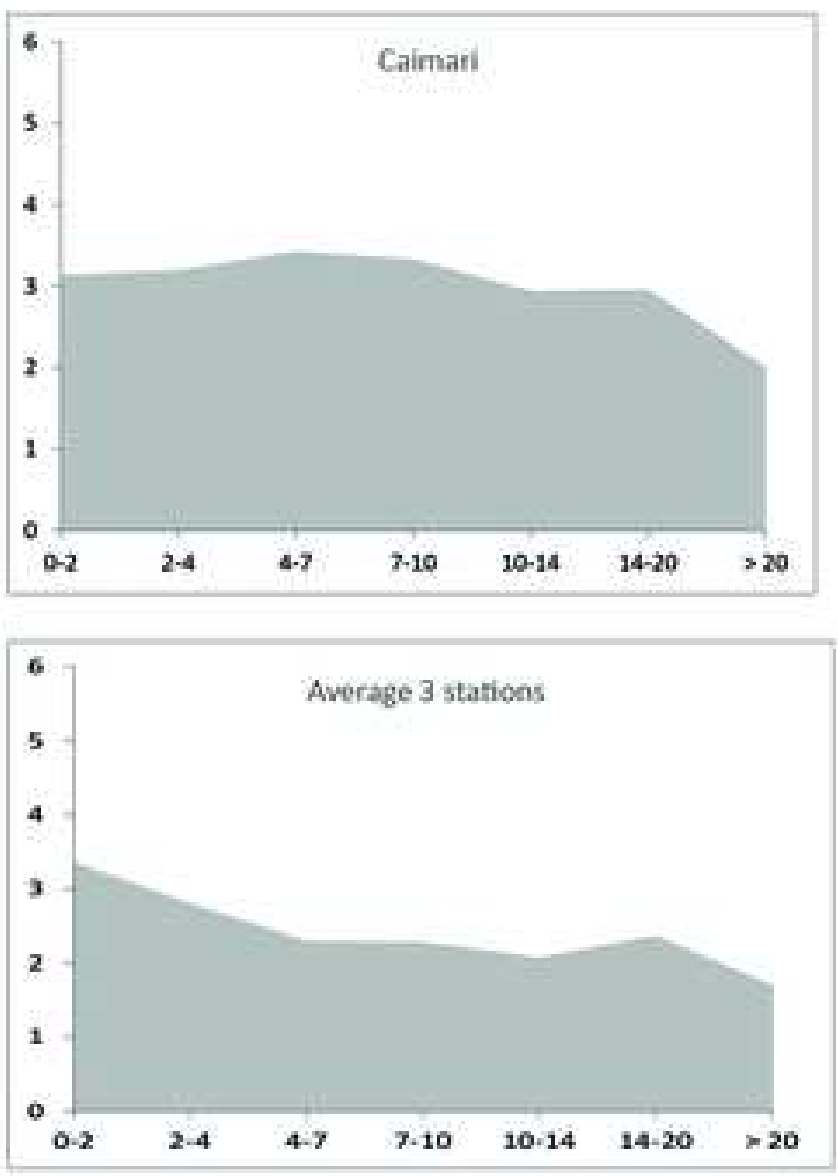
A)

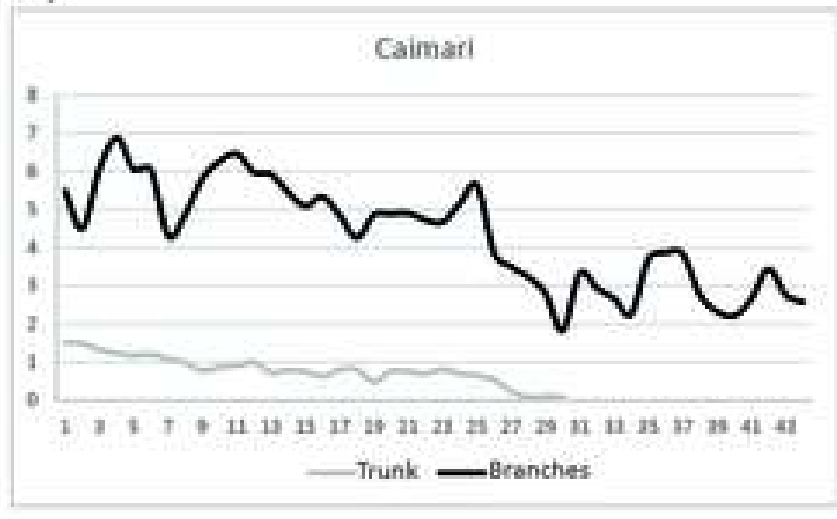

Cap Salines

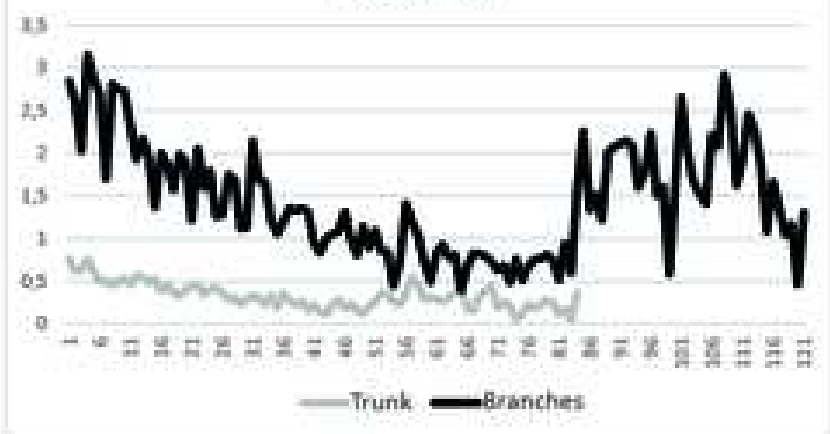

B)
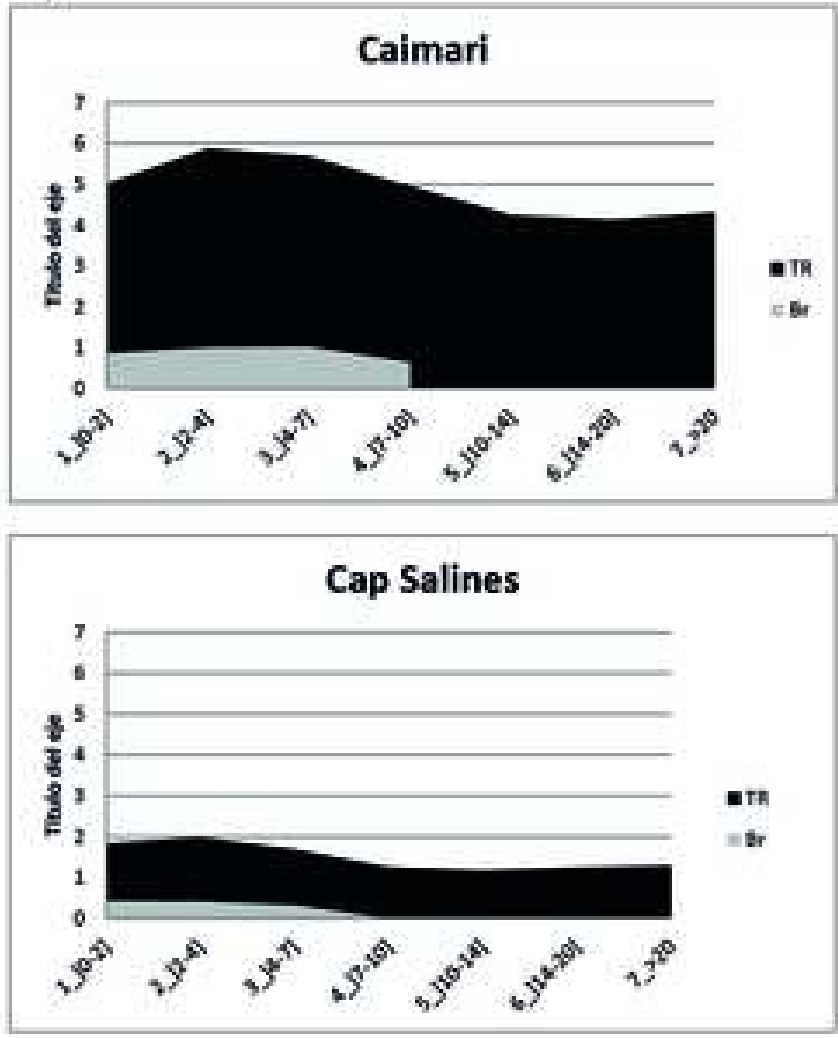
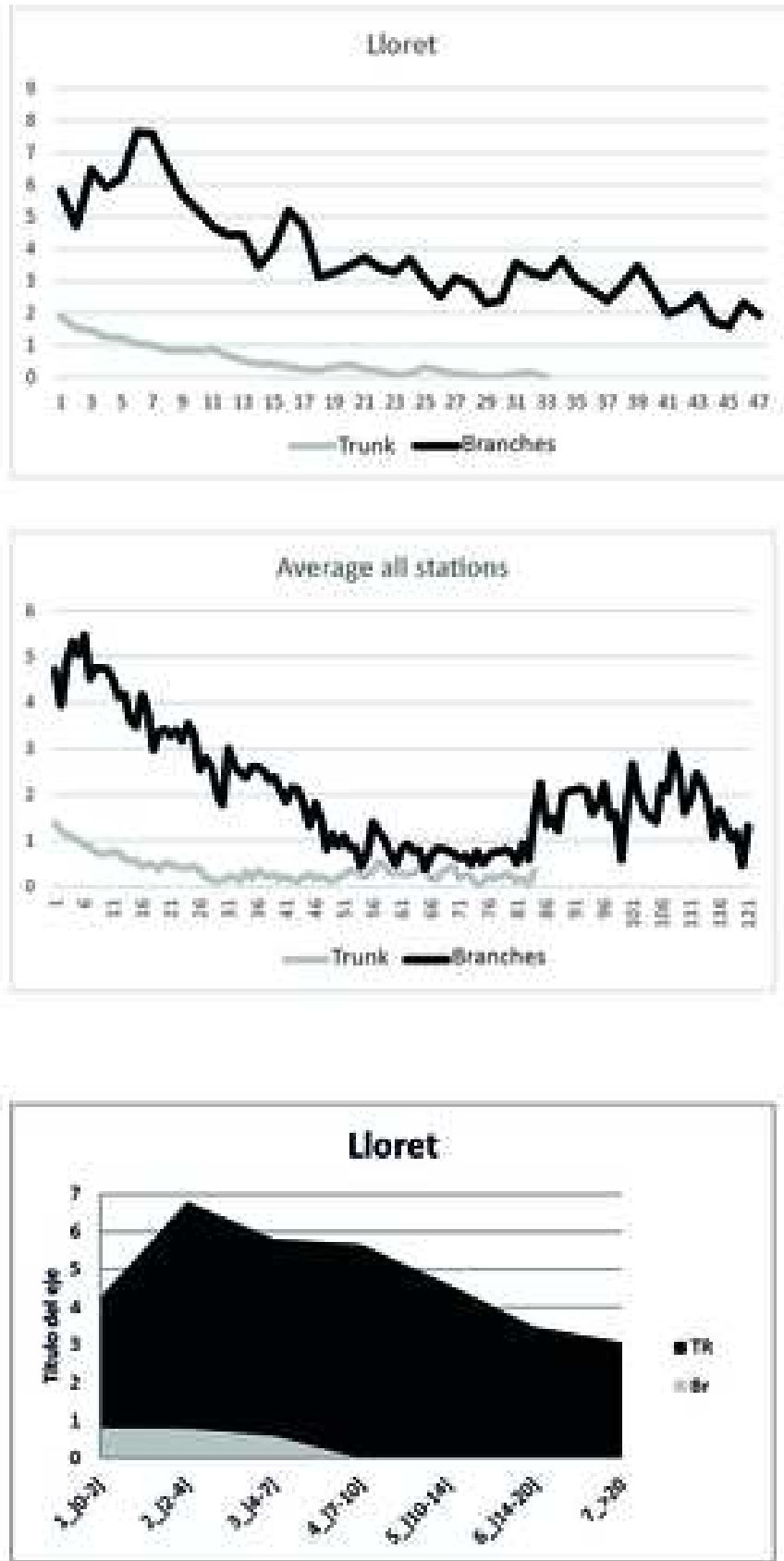

Averga all stations

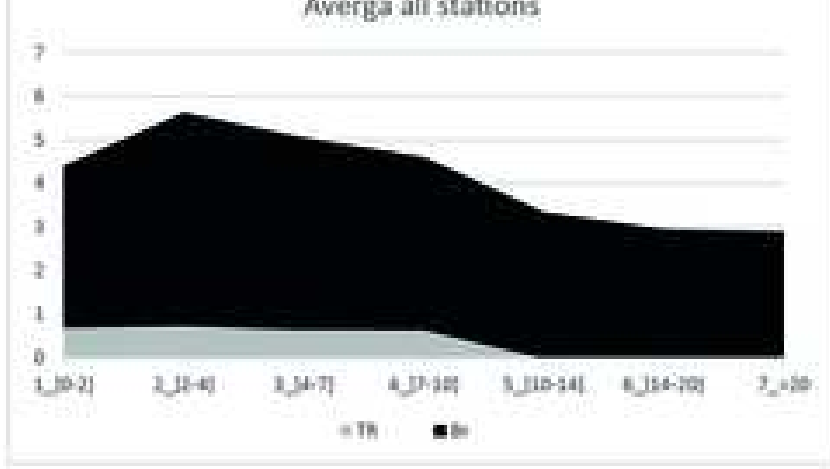


A)

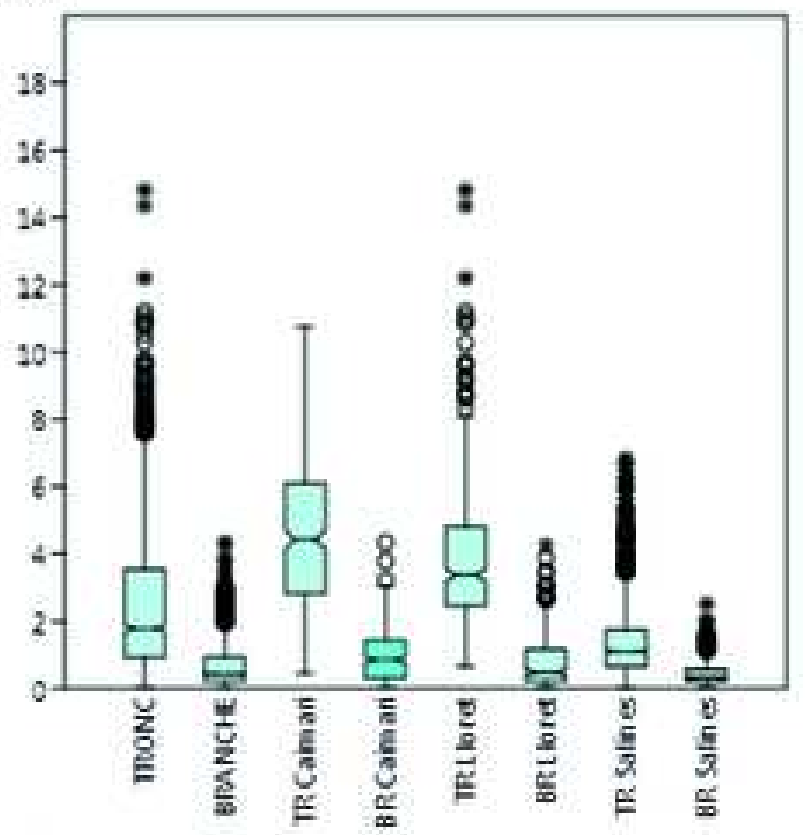

B)

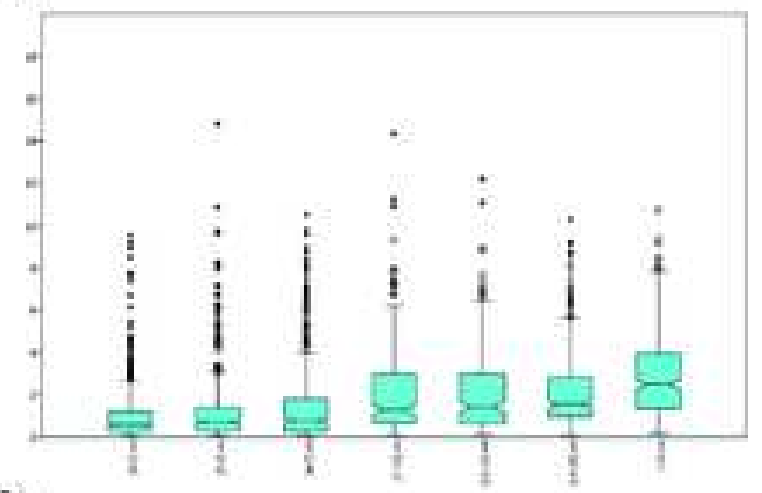

c)

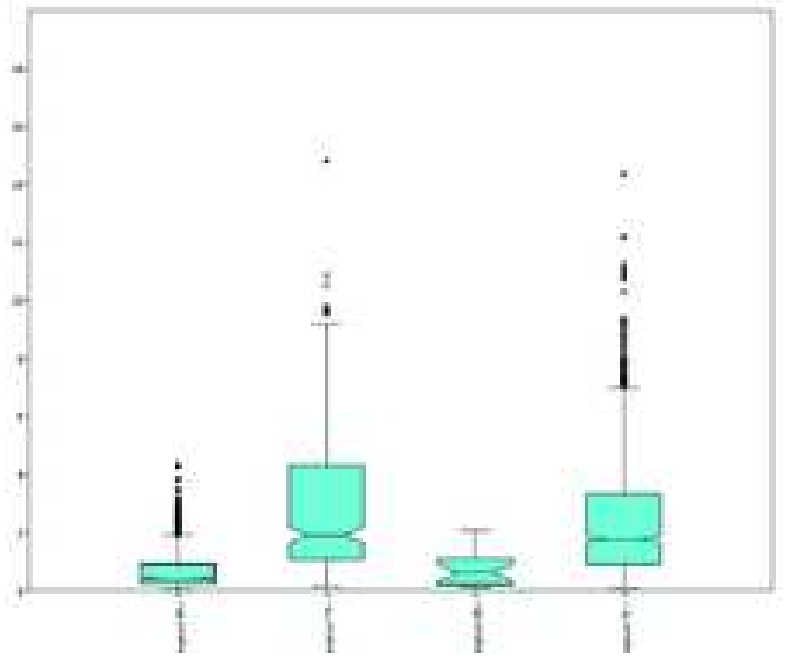

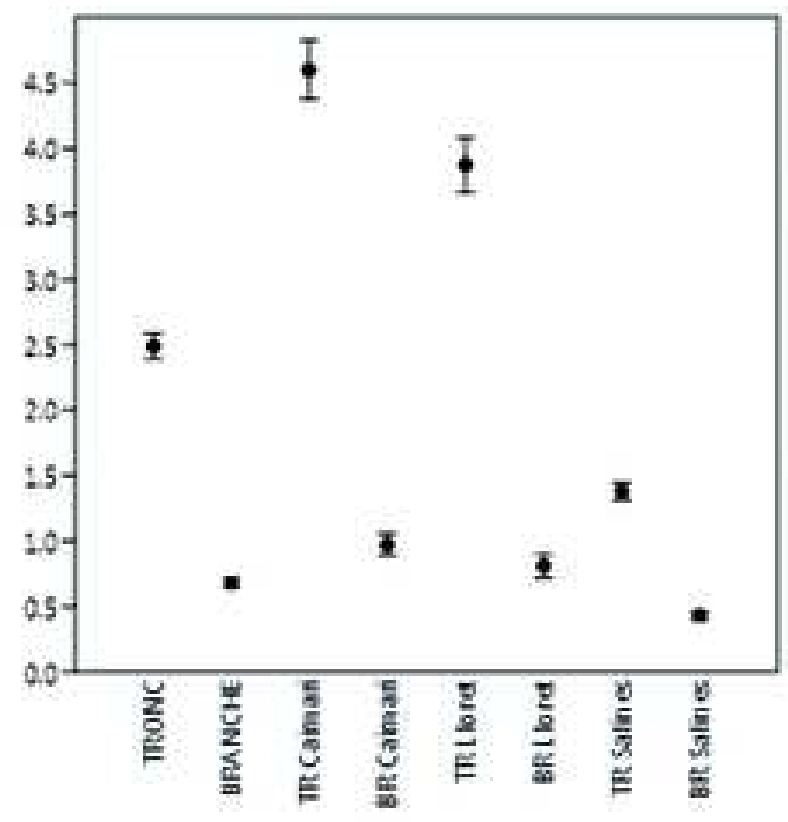
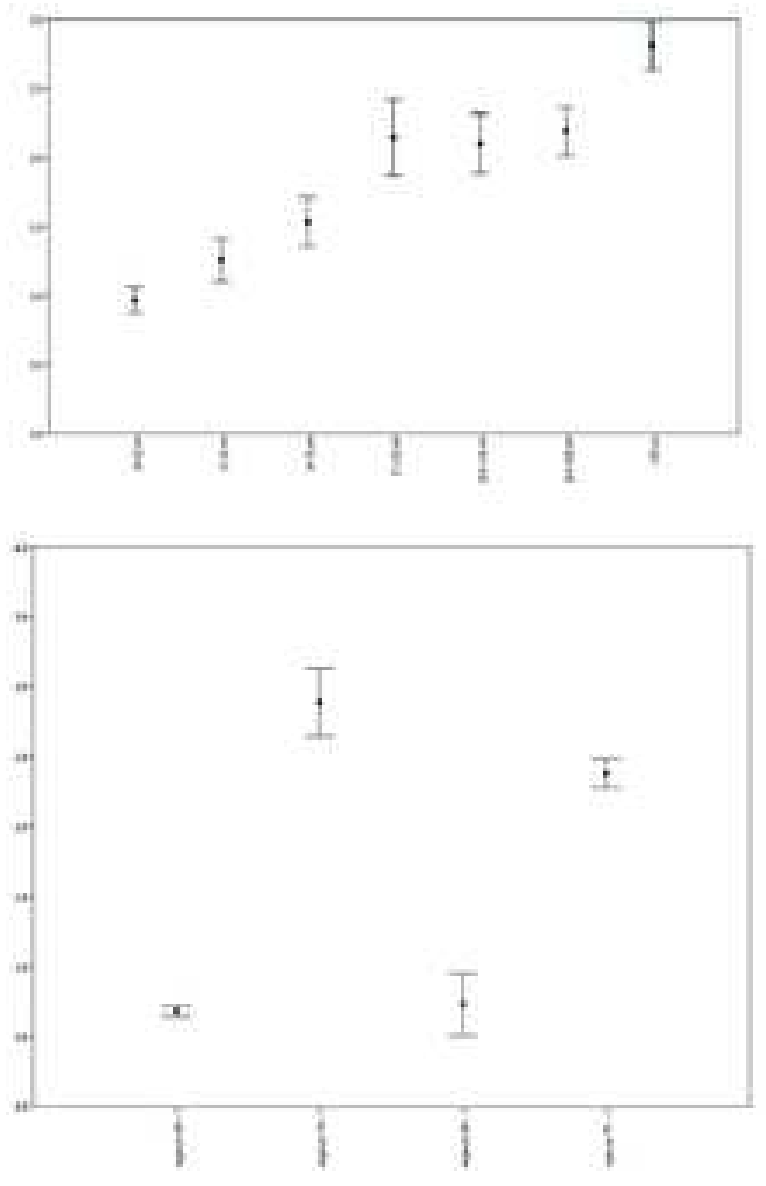
A)

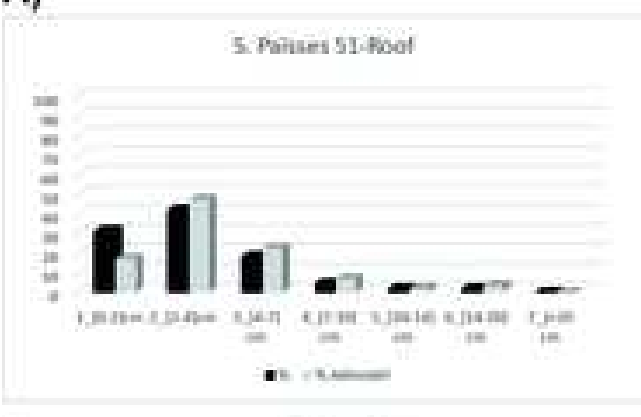

5 Palses 25

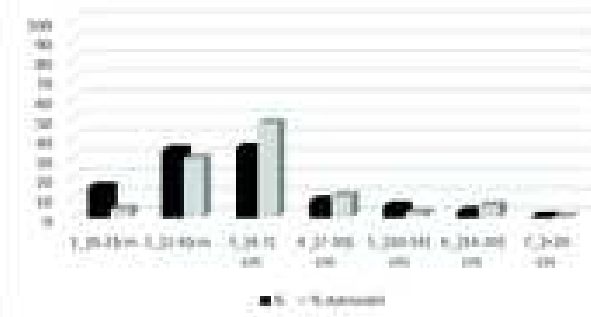

Galera - sunce

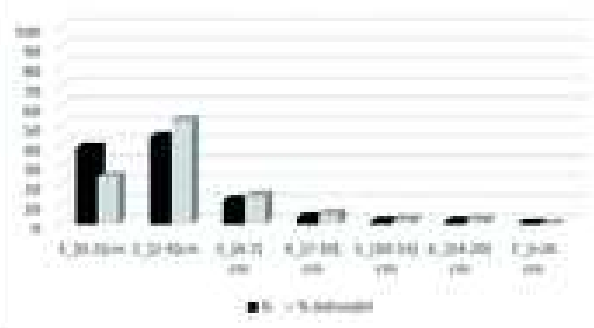

B)

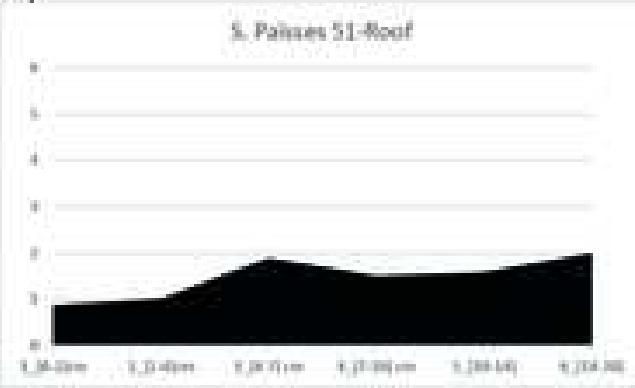

5. Patises 25

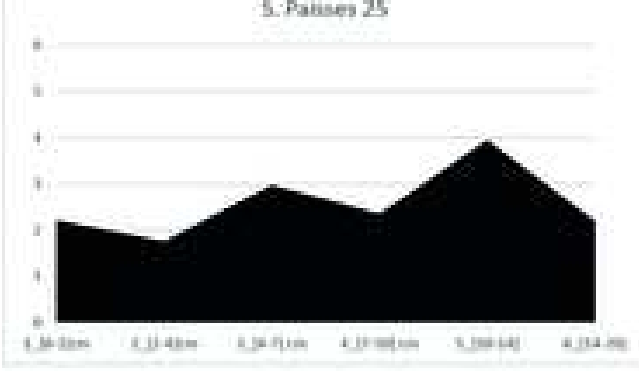

NrGelera

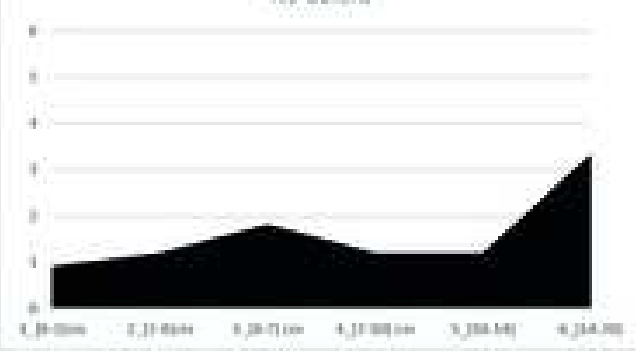

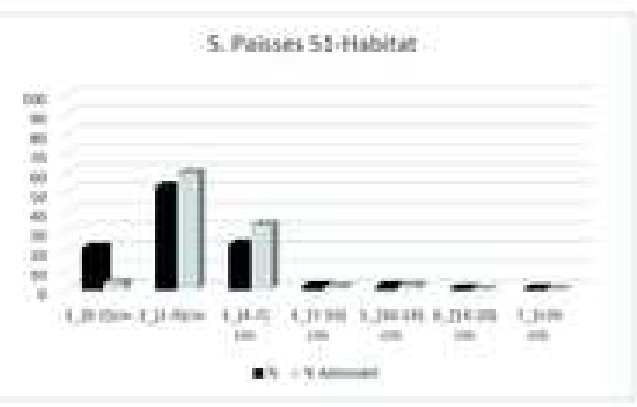

5. Fornds Tataint 3
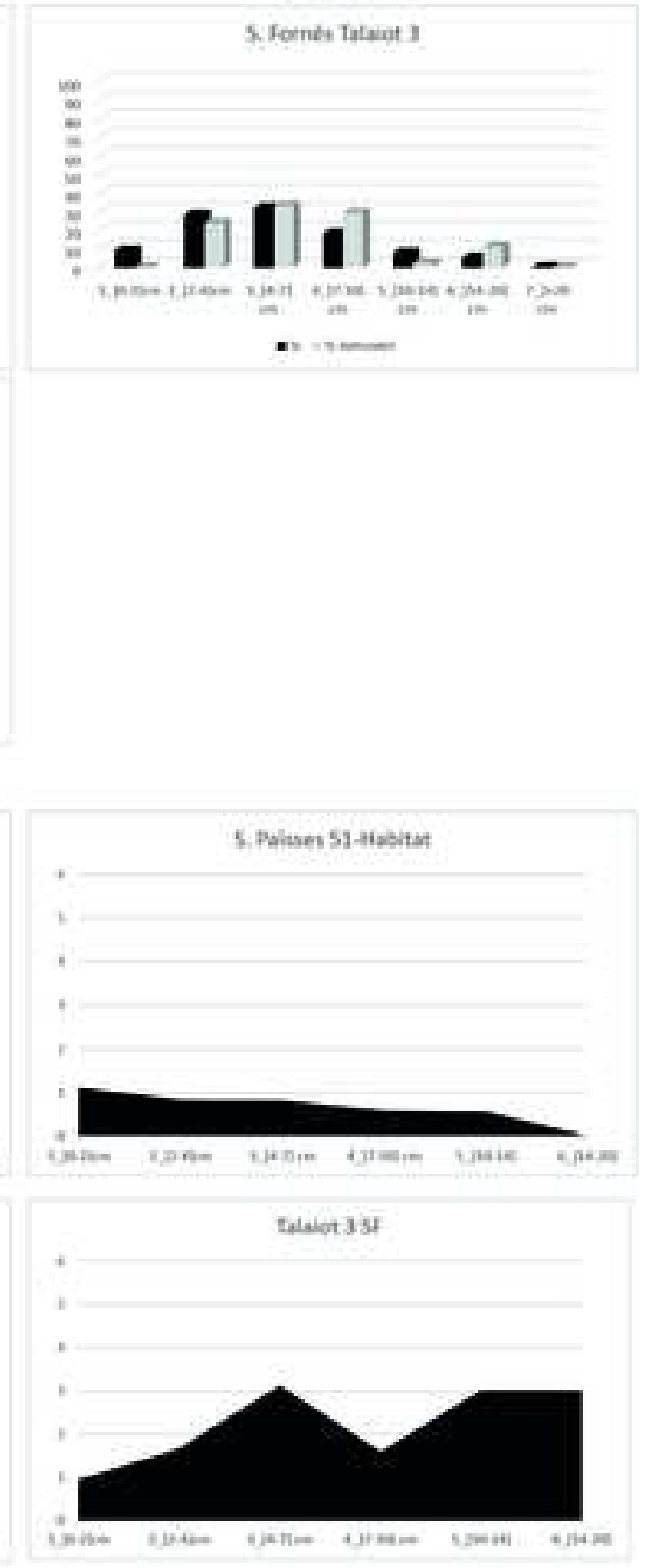

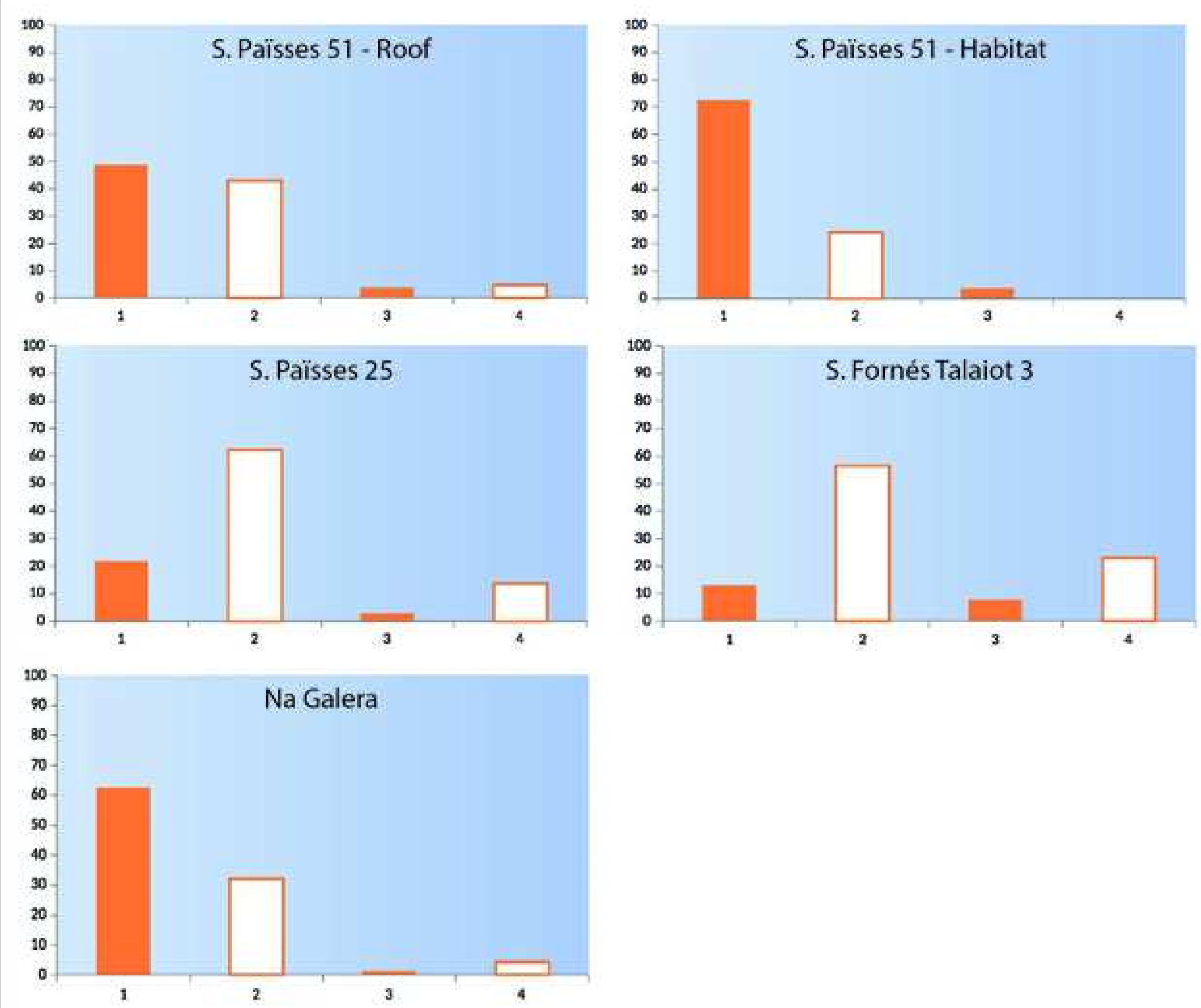

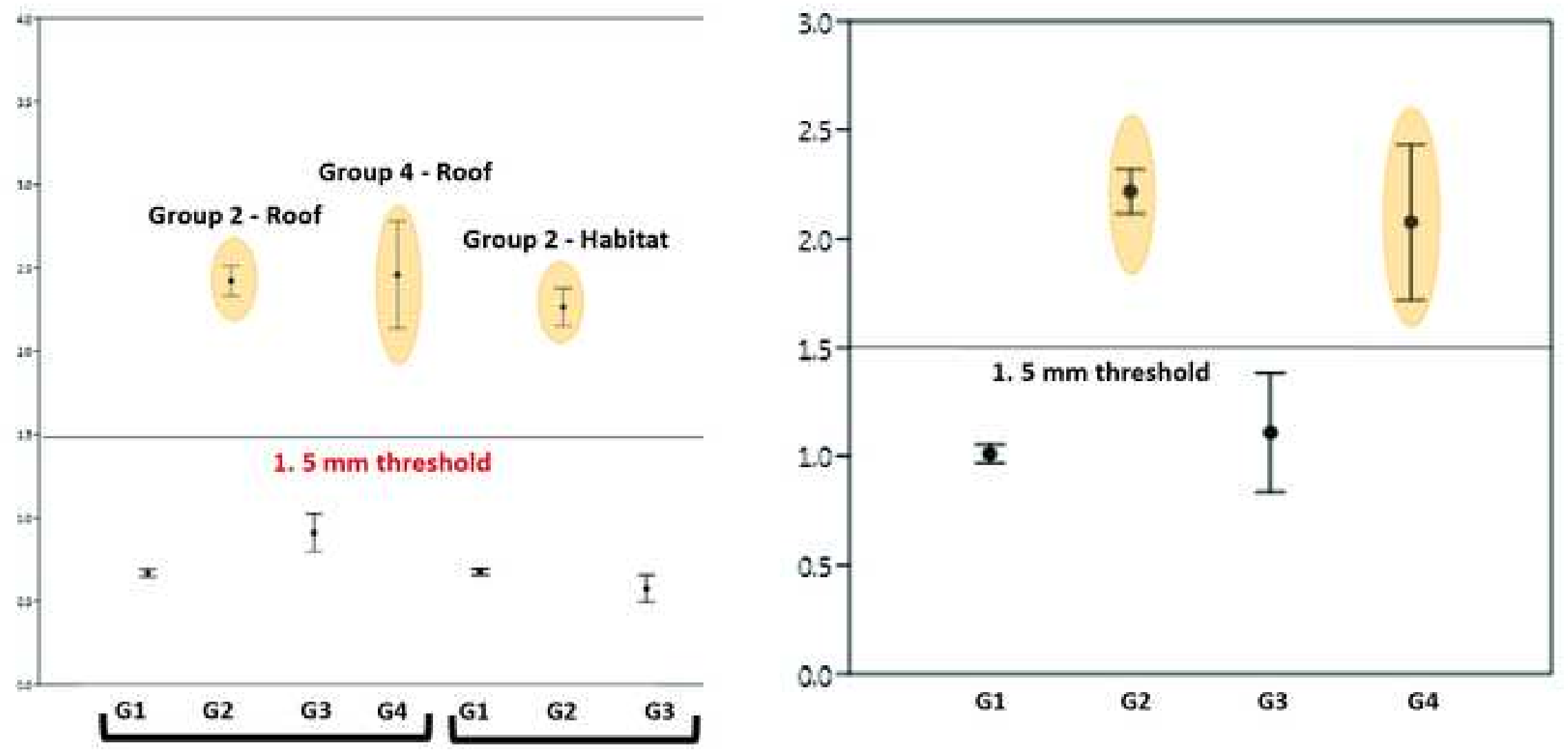
Palma, Balearic Islands, Spain

$17^{\text {th }}$ June 2020

Declarations of interest: none.

Dear editors,

We declare that there's no financial nor personal interest or belief that could affect the objectivity of our paper.

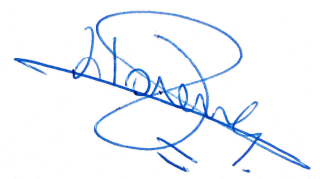

Llorenç Picornell-Gelabert (corresponding author on behalf of all the co-authors)

University of the Balearic Islands 